\title{
Brief Historical Ecology of Northern Portugal during the Holocene
}

\author{
BRUNO PINTO*
}

Department of Sciences and Environmental Engineering

New University of Lisbon

2829-516 Caparica, Portugal

E-mail:Bpinto74@gmail.com

\section{CARLOS AGUIAR}

Superior School of Agriculture, Department of Biology 5301-855 Bragança, Portugal

\section{MARIA PARTIDÁRIO}

Technical Superior Institute

Av. Rovisco Pais, 1049-001 Lisbon, Portugal

* Corresponding author

\begin{abstract}
This study reviews the main changes of the vegetation and fauna in northern Portugal during the Holocene, using literature from palaeoecology, archaeology, history, writings from travellers and naturalists, maps of agriculture and forestry and expert consultation. The ecological history of this area shows a trend of forestry decline, with periods of recovery of the vegetation related to the decrease of human pressure on natural resources. The deforestation began on the high plateaus of this region, extending later to the heavier and more productive soils of the valleys. In the beginning of the Holocene, the climate seems to have been the most important trigger of change in this area, but human impact probably became preponderant in the last 5000 years. The natural herbivorous fauna was probably reduced, with the extinction of species such as wild horse, aurochs and European beaver, and partially replaced by human action. Nevertheless, the high resilience of ecosystems has enabled their sustainability for eight millennia and has also allowed the recovery of the vegetation and fauna in the recent decades.
\end{abstract}




\section{BRUNO PINTO, CARLOS AGUIAR AND MARIA PARTIDÁRIO}

\section{INTRODUCTION}

Mediterranean ecosystems have a long history of both human and natural impacts which had profound consequences for contemporary biodiversity. ${ }^{1}$ The use of fire by humans, which dates back to the Middle Pleistocene, probably changed the natural fire regimes and the vegetation even before the Holocene. ${ }^{2}$ Despite the difficulty of distinguishing between natural and human-induced changes in the development of Mediterranean ecosystems, it is consensual that human action increased drastically with the introduction of the agro-pastoral way of life in the Neolithic. ${ }^{3}$

The classical view of the role of human action in the shaping of Mediterranean landscapes is the so-called 'Ruined Landscape' or 'Lost Eden' theory, which argues that humans were responsible for the degradation and desertification of this region. ${ }^{4}$ More recently, this theory has been contested by Grove and Rackham (2001), who stated that landscape changes were primarily a consequence of climatic change, reinforced by human impact. Other authors offer an intermediate position, arguing, for example, that excessive precipitation events are unlikely to cause significant soil erosion without prior direct or indirect human impact on the vegetation. ${ }^{5}$

Although there is a general idea about the history of changes in the Mediterranean basin, we still lack detailed information about the process of transformation and the implications this can have in the future management of this region. Moreover, this information is often scattered through different scientific fields such as palaeoecology, archaeology, history and ethnography. We consider that the long and complex history of interaction between Mediterranean ecosystems and humans could benefit from the integration of natural and social sciences, and that the combination of these different sources of information can potentially provide more appropriate explanations for the environmental history of the region. ${ }^{6}$

The objective of this study is to review the main episodes of the historical ecology of northern Portugal during the Holocene. More specifically, it aims to (1) describe the process of vegetation change; (2) review the extinction of mammal and bird species; (3) relate vegetation and fauna changes to human history and climate change events; and (4) discuss and relate these changes to other Mediterranean areas. We take an interdisciplinary approach through the integration of different sources of information. The choice of northern Portugal as a study area is related to the greater familiarity of the first two authors with this area. Although this is a peripheral area in the Mediterranean region, the history of human impacts shares many common episodes with others closer to

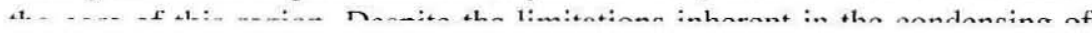


HISTORICAL ECOLOGY OF NORTHERN PORTUGAL

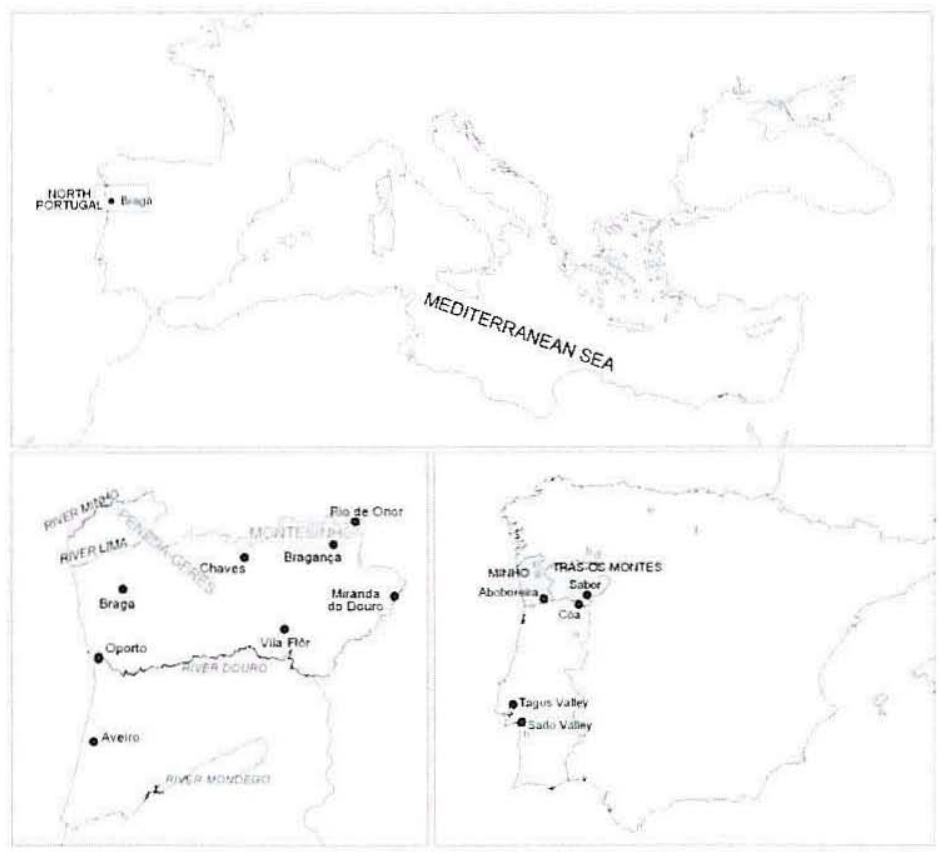

FIGURE 1. The Mediterranean Basin, Iberian Peninsula, and central and northern Portugal, showing the locations discussed. Palynological studies in: (a) van der Knaap and van Leeuwen, 1995, 1997; (b) Allen et al., 1996; (c) Ruiz-Zapata et al., 1995; (d) MuñozSobrino et al., 2004; (e) Muñoz-Sobrino et al., 2005; (f) Muñoz-Sobrino et al.,1996; (g) Ramil-Rego et al.,1998; Mateus, 1992.

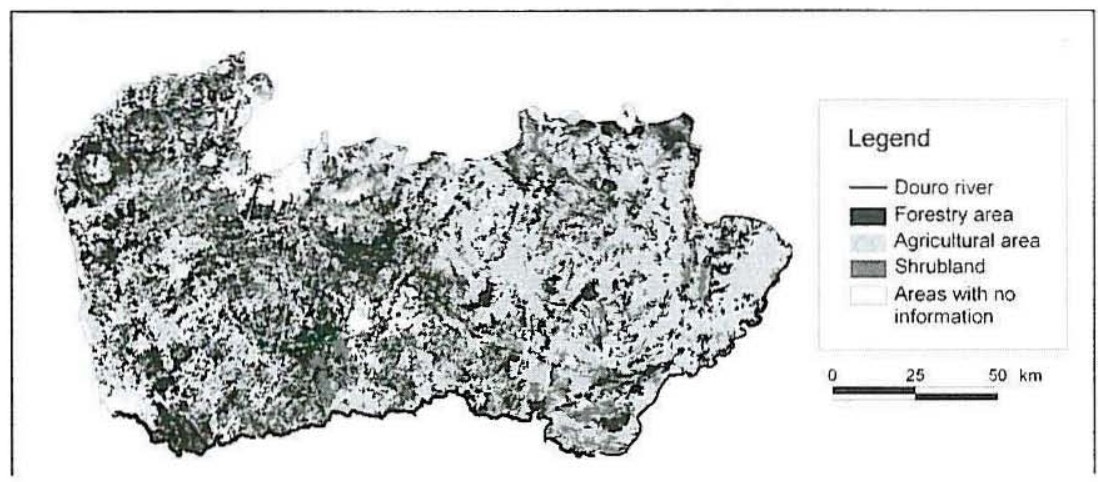


6

\section{BRUNO PINTO, CARLOS AGUIAR AND MARIA PARTIDÁRIO}

\section{METHODS}

In this study, northern Portugal was defined as the region limited by the Douro River in the south, the Spanish border in the north and east and the Atlantic Ocean to the west, covering an area of approximately $18,000 \mathrm{~km}^{2}$. The western half of northern Portugal is characterised by granite or schist erosion platforms, with wide E-W or ENE-WSW valleys filled with fluvial and colluvial deposits. Steeper landforms appear towards the east and culminate in the granites of the Galaico-Portuguese Mountains (1545 m max. alt.).

Physiography exerts a strong influence on macroclimate, vegetation and present land uses in northern Portugal. The barrier effect of the Galaico-Portuguese Mountains causes a drop in precipitation from more than $3000 \mathrm{~mm} / \mathrm{year}$ to less than $400 \mathrm{~mm} /$ year in a $100 \mathrm{~km}$ transect. Consequently, along these mountains there is an unusually sharp boundary between the Eurosiberian and the Mediterranean Phytogeographic Regions ${ }^{8}$ and between temperate and Mediterranean macro-bioclimate and agricultural systems.

A temperate macrobioclimate dominates in the $\mathrm{NW},{ }^{9}$ with a sub-mediterranean influence, revealed by a significant summer drought ( $>1$ month). The lowland tree layer is composed of Quercus robur and Quercus suber and above $800-900 \mathrm{~m}$ altitude, natural forests are dominated by Quercus robur and Quercus pyrenaica. The main actual land cover types are agriculture, plantations of Pinus pinaster and Eucalyptus globulus, tall shrublands of Cytisus striatus and Adenocarpus lainzii and mixed low shrublands of Ulex sp. and Erica sp.

In the mountains, chestnut orchards are fundamental to local economies, particularly in Mediterranean territories. In temperate mountains, semi-natural pastures and low shrublands are grazed by small regional cattle breeds. In the Mediterranean mountains and plateaus, heathlands are managed with fire to provide food for regional breeds of sheep and goat. The Mediterranean vegetation is composed of Quercus pyrenaica and, on steep sunny slopes, Quercus rotundifolia.

The forests in the study area usually reach $650-750 \mathrm{~m}$ altitude, and occur along the main river valleys. Quercus suber is the dominant tree species in zonal soils in sub-humid areas. On deep granitic soils or pediment deposits, these forests include Quercus suber, Quercus rotundifolia and Juniperus oxycedrus trees. In deep dry valleys, there are still appreciable stretches of the former Quercus rotundifolia and Juniperus oxycedrus forest. The most important cultivated plants in the Mediterranean areas are vines, olive trees, almond trees and wheat. Marginal lands are frequently covered with thick low shrublands of Cistus ladanifer. There is a generalised pattern, frequent in other Mediter- 
HISTORICAL ECOLOGY OF NORTHERN PORTUGAL

In relation to the population, northern Portugal follows the national trend, with a concentration in the coastal regions. Population density in the northeast is generally low (below 50 inhabitants per $\mathrm{km}^{2}$ ) and is decreasing, and most of the working population is employed in agro-pastoral activities. In the northwest, the population density is higher and increasing, and most people in the region are employed in industry and services."

\section{Sources of information}

This study reviews the main changes of the vegetation and fauna in northern Portugal during the Holocene, using literature from palaeoecology, archaeology, history, writings from travellers and naturalists, maps of agriculture and forestry and expert consultation. The information used is described below in more detail. All the dates mentioned in the text were obtained from radiometric dating using ${ }_{14} \mathrm{C}$ (radiocarbon) without calibration or estimated dates, except in the case of the climatic data taken from Desprat et al. (2003) who used ${ }_{14} \mathrm{C}$ dating with calibration, which are referred to as 'cal'.

The proxy evidence provided by charcoal data collected in Portuguese archaeological sites and NW Iberia palynological surveys are the main sources of information for northern Portugal's palaeoenvironmental reconstitutions. Pollen record similarities in NW Iberia are higher inside the same actual biogeographical units. ${ }^{12}$ For eastern areas, the most reliable palaeopalynological information comes from Secundera Mountain in Spain. ${ }^{13}$ However, these were used with caution for Mid and Late Holocene palaeoenvironmental reconstitutions, because northern Portugal's continental mountains have a plain morphology and are much lower than Secundera Mountain. For these reasons, pollen data from Estrela Mountains (central Portugal) was also used, especially for periods after the Neolithic (See Diagrams 1 and 2). ${ }^{14}$ Present-day vegetation ecology was also a fundamental component in the interpretation of pollen data. The uniformitarian assumptions it involves are more speculative when pollen data or charcoal deposits are scarce or absent, as is the case in the lowlands of northern Portugal.

Palaeoecological literature was also used to assess Holocene climate changes in the study area, through the information drawn from Allen et al. (1996), Ramil-Rego et al. (1996) and Desprat et al. (2003), in which pollen data was used to characterise the climatic changes. The results of these two studies are summarised in Table 1.

Since northern Portugal has little information concerning the palaeofauna, due to the predominance of acid soils in which bone preservation is poor, some of the data presented is drawn from archaeological studies conducted in central 
BRUNO PINTO, CARLOS AGUIAR AND MARIA PARTIDÁRIO

groups. Other studies in archaeology detailing the excavations in a rock-shelter during the Neolithic or the human occupation during the Roman times were also consulted. ${ }^{15}$ History books and papers were used to collect information related to Portuguese forests such as demographic variations, and human activities such as agriculture, animal husbandry and hunting pressure.

\section{Writings of travellers, naturalists and hunters}

Literary sources on northern Portugal which were considered in this review include writings from classical authors and books from the sixteenth to the early twentieth century. ${ }^{16}$ Some of these books were particularly useful, since they were written by naturalists whilst living in or travelling through the study area. In a few cases where books are written in an apologetic tone to please a patron, the information was discarded if there was no confirmation of its validity through other sources. ${ }^{17}$ From the nineteenth and twentieth centuries, there are also several descriptions in the press of hunting trips to the mountain areas of this region, which were used as a source of information.

\section{Historical and present-day studies of agriculture, forestry, fauna and ethnography}

Previous studies about the forest and agriculture in Portugal for specific periods such as between the fifteenth and sixteenth centuries and from the nineteenth century to the present were used in this review. Other studies about subjects such as ship construction during the Portuguese Expansion were also consulted. ${ }^{18}$ In relation to cartographic information, the map from Higounet (1996) in Williams (2000) of the major forest areas in Europe between the fifth and eleventh centuries and the Portuguese map of agriculture and forestry from 1910 were both used for a general assessment of the land uses of northern Portugal in these two different time periods. Previous studies of historical information on the fauna in Portugal, and present-day studies of vegetation, fauna and ethnology were used for the more recent past. ${ }^{19}$ Finally, ethnographical studies concerning mountain villages in northern Portugal were also consulted to enable a more socio-economic perspective of the exploitation of the natural resources. ${ }^{20}$ 


\section{HISTORICAL ECOLOGY OF NORTHERN PORTUGAL}

\section{RESULTS}

\section{Transition from the Late Pleistocene to the Holocene}

The last glacial maximum in the Iberian Peninsula is estimated to have occurred between 20,000 and $18,000 \mathrm{yr} \mathrm{BP}$ (nineteenth and eighteenth millennium $\mathrm{BC}$ ). At the end of this period, the higher mountains of northern Portugal were permanently, or at least for most of the year, covered with ice. Perpetual snows persisted at about 1100-1200 metres and extensive ice sheets accumulated at lower altitudes in more continental areas. ${ }^{21}$ The areas under greater maritime influence were more humid than continental ones and sheltered more tree communities.

Climatic conditions in northern Portugal began to improve at about 16,000 yr BP (fifteenth millennium BC) and triggered a period of deglaciation with an approximate duration of 3000 years. Between 13,000 and $11,000 \mathrm{yr} \mathrm{BP}$ (twelfth and eleventh millennium $\mathrm{BC}$ ), during the Late-glacial Interstadial, there was an accentuated increase in temperature and precipitation, which promoted an expansion of tree taxa and the decline of steppic vegetation. ${ }^{22}$ This trend occurred earlier and was more pronounced in the more oceanic and humid western mountains and plains because the arboreal lowland vegetation was already significant. During this period, there was a short peak of expansion of Betula sp., before an expansion of Pinus sylvestris, which was followed by an increase of English oak (Quercus robur). Between 11,000 and 10,000 yr BP (tenth millennium BC) (Younger Dryas), there was a contraction of the tree line and an increase of the representation of herbaceous and shrub species in the mountains, with higher representation of other species in pollen assemblages of continental territories (see Diagram 1).Precipitation decrease played a larger role in these vegetation changes than temperature. ${ }^{23}$

As previously described, the physiognomy of northern Portugal is characterised by deep valleys, which apparently served as refuge areas for the vegetation during cold and dry periods. These areas were also important for the mammalian fauna, which probably moved along the valleys, as well as mountain tops. The oldest palaeolithic engravings in the valleys of Foz Côa (border area between central and northeast Portugal) are estimated to be datec' $22,000-20,000 \mathrm{yr}$ BP (twenty-first and twentieth millennium BC), and represent wild goats (Capra sp. and Rupicapra rupicapra), aurochs (Bos primigenius) and wild horse (Equus caballus). Recent findings of palaeolithic engravings along the River Sabor (NW Portugal) represent aurochs and wild horses..$^{24}$ The presence of both Capra pyrenaica and $C$. ibex in Portugal is not certain, since the bones of these species are very difficult to distinguish..$^{25}$

Tho I ato olosial Intarctadial had an imnact on the faunal remnncition Ac- 
10

\section{BRUNO PINTO, CARLOS AGUIAR AND MARIA PARTIDÁRIO}

scrofa).${ }^{26}$ However, it seems likely that a species of wild goat (Capra pyrenaica) continued to exist in the higher mountains of northern Portugal throughout the Holocene, since it became extinct in the Peneda-Gerês mountains in 1890.27 Other herbivore species such as wild equids (Equus caballus antunesi and possibly Equus hydruntinus) and fallow deer (Dama dama) became extinct before the beginning of the Holocene.$^{28}$ During the late-glacial interstadial, the composition of hunted mammalian archaeofauna became largely dominated by the red deer (Cervus elaphus), but other species such as wild rabbit (Oryctolagus

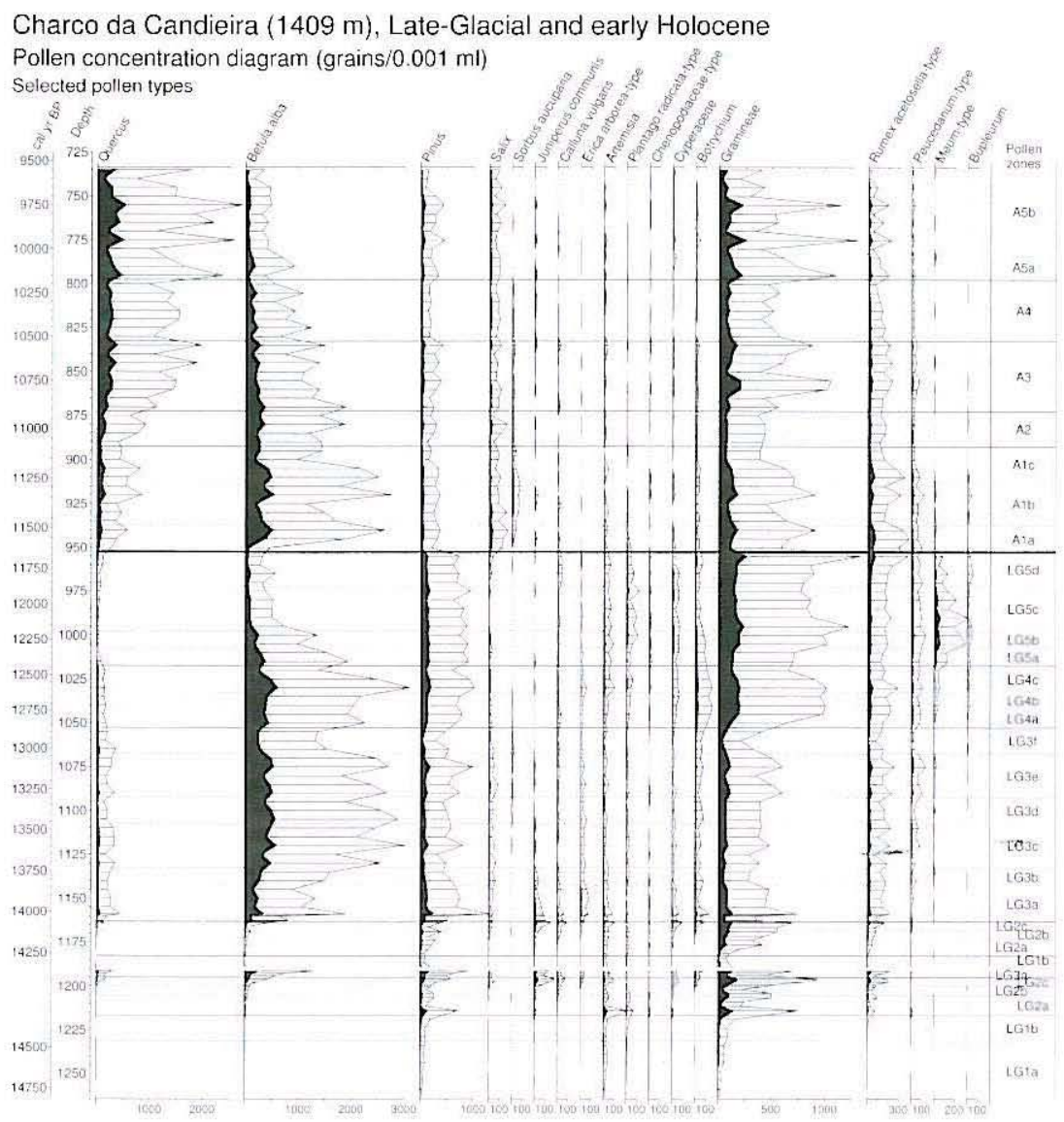




\section{HISTORICAL ECOLOGY OF NORTHERN PORTUGAL}

cuniculus), aurochs, roe deer and wild boar are also found in archaeological sites. It is interesting to note that, in the Foz Côa Palaeolithic engravings, red deer also became much more common during the Epipalaeolithic. ${ }^{29}$

Pollen analysis in NW Iberia does not allow for the distinction between natural changes in the vegetation and human activities, which apparently indicates that the latter had a small influence on the vegetation. However, it is known that the new tool technologies and a more efficient social organisation of the Upper Palaeolithic human populations enabled an increased human influence upon their environment. It is also unclear if hunting contributed to the decline and/or extinction of mammal species that preceded the Holocene in northern Portugal. Several authors suggest that the extinction of chamois (Rupicapra rupicapra) and the decline of species such as wild horse and aurochs were a consequence of the forest expansion before the Holocene. ${ }^{30}$ On the other hand, it has also been suggested that extinctions during the Late Pleistocene were due to the combination of both anthropogenic impacts and climatic changes.31

\section{The Early Holocene}

In the beginning of the Holocene, climate warming contributed to the replacement of steppe and shrub vegetation in the mountains by forest. Pollen data usually shows an initial peak of Pinus sp. and Betula sp., followed by a lasting expansion of Quercus sp. ${ }^{32}$ (see Diagram 1). The definitive dominance of forest was a rapid event due to the plain morphology of the northern Portugal highlands. In the NE valleys, steppes with dispersed Iuniperus sp. and/or Pinus sp. were replaced by Quercus rotundifolia and Quercus suber forests. Forced by competitive exclusion with Quercus sp., Pinus sylvestris was pushed to higher altitudes until it became extinct in the Portuguese mountains. Although climate warming is the most likely cause for the decline of this species, soil pedogenesis, the shortening of the recurrence period through human-induced fires and the stagnation of the spread to other areas due to increased rainfall are also possible explanations. ${ }^{33}$

In the archaeological sites of the Mesolithic located in the coastal and fluvial areas of the valleys of the rivers Tagus and Sado (Central Portugal), it was found that species such as red deer, wild boar, aurochs (Bos primigenius) and wild horse (Equus caballus) continued to be hunted. Since there is only scarce evidence of human occupation in the interior of Portugal, it has been proposed that the vegetation and fauna changes in the transition to the Holocene forced humans to alter their subsistence strategies, increasing the exploitation of aquatic resources around coastal and fluvial areas and abandoning the densely wooded interior. ${ }^{34}$ 
BRUNO PINTO, CARLOS AGUIAR AND MARIA PARTIDÁRIO

The changes in the landscape and fauna in the transition to the Holocene probably have lead to changes in hunter-gatherer strategies, in which vegetation management assumed greater importance ${ }^{37}$ Vegetation management could be achieved using primitive tools and/or fire to create open areas with herbaceous and shrub vegetation, which favoured the presence of steppe birds (e.g. red partridge) and large herbivores such as wild horses and aurochs, and improved the ability to observe wild animals and so improve hunting success. ${ }^{38}$

Several sources of evidence suggest that the Mediterranean ${ }^{39}$ and Central European ${ }^{40}$ biotopes were composed of a mosaic of successional stages before human disturbance became significant. In a territory with sub-Mediterranean or Mediterranean climate with a strong relief such as in northern Portugal, a complex panoply of disturbance types - fire, landslides, herbivory, tree diseases, tree decrepitude - converged and promoted the development of heterogeneous vegetation mosaics in ecologically homogeneous areas. These mosaics certainly varied from almost continuous fine-grained forests to heterogeneous vegetation complexes, where climax forests coexisted in a shifting mosaic with various types of herbaceous low shrub and tall shrub communities and secondary forests. Since there is evidence of small-scale anthropogenic deforestation in Estrela Mountains more than 8,500 years ago, human actions also contributed to this diverse mosaic of successional stages. ${ }^{41}$

\section{From the Neolithic to the Bronze Age}

According to the maritime pioneer colonisation model, the Neolithic in Portugal has its origin in the colonisation by small seafaring groups of agriculturalists coming from the Mediterranean region in the sixth millennium $\mathrm{BC}^{42}$ The introduction of this agro-pastoral way of life coincides with the beginning of the Climatic Optimum, when the temperature and humidity reached a peak. ${ }^{43}$ The Neolithic groups probably expanded from the coastal areas of southern Portugal and became rapidly established in the interior regions, thus competing and overcoming the existing groups of hunter-gatherers. The first agro-pastoral communities practised a shifting agriculture. In the Buraco da Pala, a rockshelter in Mirandela (NE Portugal), evidence of wheat, barley and broad bean were recovered from the first phase of human occupation. This occupation had a seasonal character and was used for domestic consumption, occurring between the end of the sixth and beginning of the fifth millennia $B C$ to the end of the fourth millennium $\mathrm{BC}^{.4}$

The consolidation of the agro-pastoral system in northern Portugal during the fourth millennium $\mathrm{BC}$ implied the deforestation of considerable areas. The 
HISTORICAL ECOLOGY OF NORTHERN PORTUGAL

several archaeological sites. ${ }^{46}$ Moreover, palynological studies of mountains in northwest Iberia also show that significant deforestation started around the mid-fourth millennium Bc. In this process, human-induced fire combined with animal husbandry and, to a lesser extent, primitive tools were used extensively, as has been described in other Mediterranean regions. ${ }^{47}$ Therefore, the megalithic culture that built impressive stone structures throughout northern Portugal during the fourth millennium $\mathrm{BC}$ was also responsible for the beginning of large-scale deforestation in this area. ${ }^{48}$

In the third millennium BC (i.e. beginning of the Bronze Age), palynological studies show an intensification of deforestation in northern Portugal. ${ }^{49}$ In the Estrela Mountains, large fires with possible human origin are recorded around $4,300 \mathrm{yr}$ BP (third millennium BC) which devastated and changed the vegetation in this area. This is followed by the first sign of cereals in the pollen archives ${ }^{50}$ (see Diagram 2). About 1000 years later, there was a new and more intense phase of deforestation in this area, which is synchronous with the strong decline of trees in the mountains of northwest Iberia, recorded between 3,500 and 3,000 yr BP (second millennium BC).$^{51}$ In a similar pattern, this was also accompanied by the presence of cereals in the palynological records.

According to the secondary products revolution, the continuous expansion to new agricultural areas is related to an increase in population and the beginning of the use of animal traction and the plough in agriculture..$^{52}$ Although there is still no direct evidence of this technological change in northern Portugal, there are arguments which support this hypothesis. For example, in the third millennium $\mathrm{BC}$, the above-mentioned rock-shelter of Buraco da Pala began to be used for large-scale storage of cereals, which points to an increase in agricultural production and human population. Moreover, there is also direct evidence of animal husbandry during this millennium in a reasonable number of archaeological sites of northern Portugal. The third millennium BC is also characterised by the diversification of economic activities which can be a consequence of population growth, since artefacts such as net/loom weights and arrowheads found in archaeological sites suggests fishing/weaving and hunting in the region. ${ }^{53}$

The settlements in mid-mountain areas of irregular terrain during the transition from the third to the second millennium $\mathrm{BC}$ indicates a complementary use of the mountain and the valley areas. ${ }^{54}$ Climate warming may have promoted valley transhumance in these regions. This period of transition is also characterised by increased production of bronze artefacts and the increase of processes of social differentiation. Therefore, there is a diversification of human settlement systems, which at the beginning of the first millennium BC resulted in settlements located in higher areas with natural and artificial conditions of defence and other settle- 
of ecological succession and a stabilisation of the herbaceous vegetation. ${ }^{56} \mathrm{~A}$ recent study showing the increase of biomass burning in Europe since the fifth millennium $\mathrm{BC}$ corroborates the wide use of human-induced fires throughout this region during the Neolithic. ${ }^{57}$ The agriculture practised in these deforested areas was characterised by short periods of cultivation and the use of fire and domestic animals to control vegetation succession and soil fertilisation,,$^{58}$ with prolonged periods of abandonment, which enabled a partial restoration of the forest or (in E. Boserup's terms) a long fallow cycle, with no crop rotation nor use of organic fertilisers.

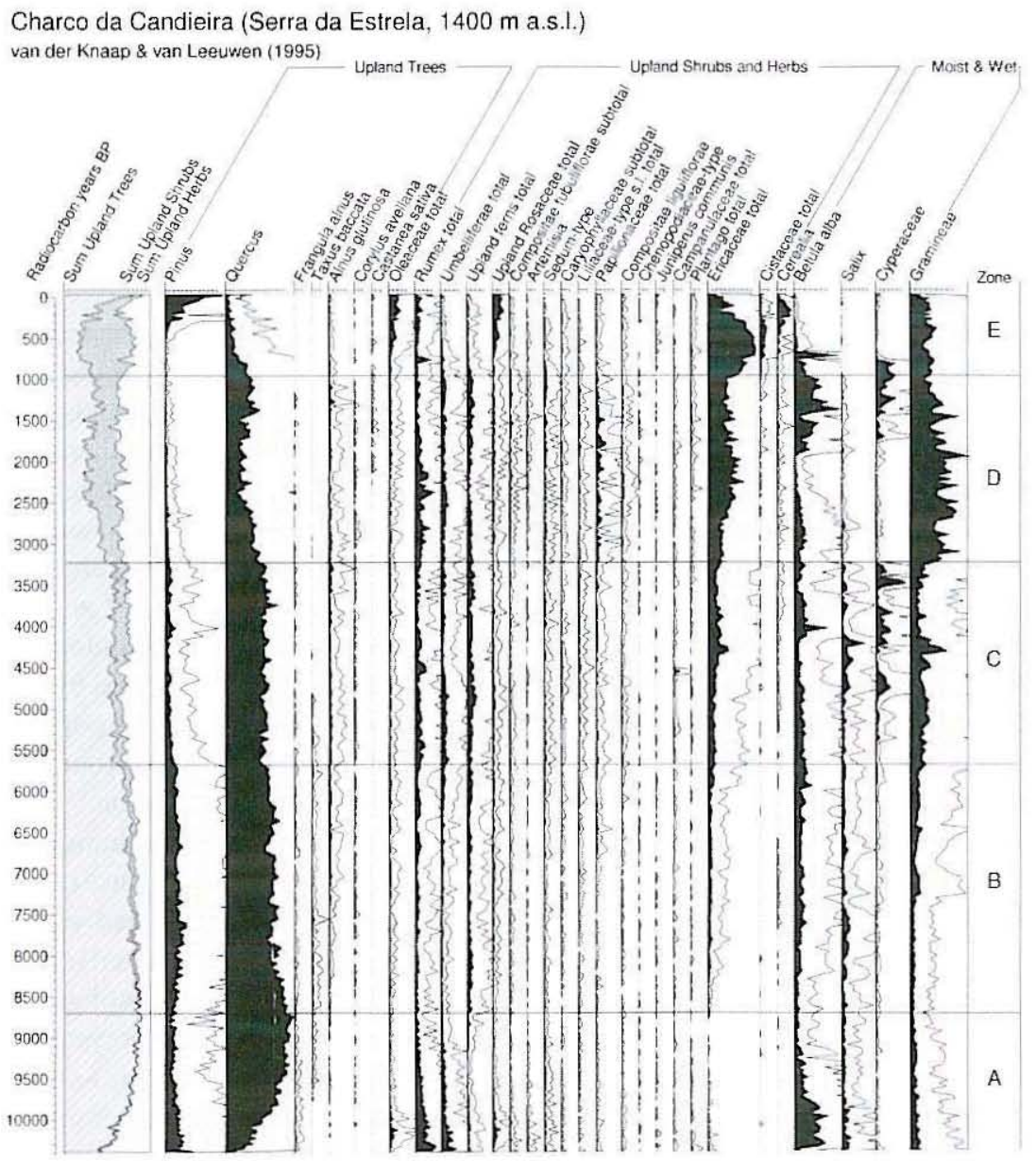


HISTORICAL ECOLOGY OF NORTHERN PORTUGAL

This incipient agriculture began in northern Portugal in the central plains of Trás-os-Montes, Minho and Douro (mostly above 700 metres a.s.l.), extending later to the valleys, where the forests were more resilient and had more biomass. ${ }^{59}$ The spatial enlargement of these agricultural practices and the probable shortening of the rotation periods promoted significant changes in the landscape. Several authors argue that extensive open areas were normal features in northern Portugal as early as the Bronze Age, at least on hill tops and plateaus, and existed side-by-side with wooded areas, which were mostly located in valleys. ${ }^{60}$ The relative abundance of forests in the valleys of northeast Portugal as late as the 1920 s seems to indicate that winter pastures were never a limiting factor for regional animal husbandry. These arguments are reinforced by the fact that written accounts by Roman authors when arriving in the Portuguese territory describe the landscape as deforested in mountain areas. ${ }^{61}$ On the other hand, prehistoric settlements in northern Portugal are more frequent at higher altitudes, which seems to reflect a more intense human occupation of the mountains. ${ }^{62}$ Nevertheless, there are temporary settlements in areas of low altitude at the end of the Bronze Age in the Minho region (NW Portugal), which were abandoned during the Iron Age, where intensive agriculture was practised. ${ }^{63}$.

In relation to the fauna, several archaeological sites in the Coa area (border of central and northern Portugal) from the Neolithic and Bronze Ages showed that, besides domestic animals such as ovines and caprines, there was also consumption of wild animals such as wild boar and red deer ${ }^{64}{ }^{64}$ Aurochs became extinct in Portugal in the Neolithic and the wild horse in the Chalcolithic or Bronze Age. In the case of the domestic horse, some authors argue that it was introduced to Portugal between the Late Chalcolithic and the Bronze Age, whereas others suggest that humans domesticated wild horses in the Iberian Peninsula during this period. ${ }^{65}$ Deforestation probably also had a detrimental effect on species which are more dependent on forest-type habitats such as roe deer and brown bear (Ursus arctos) and may have benefited other species which prefer more open habitats.

Since there is no detailed information about the composition and abundance of wild and domestic herbivores during this period, it is difficult to speculate about the changes in their effect on natural vegetation. Nevertheless, it seems likely that the extinction and/or decline of herbivores such as wild horse, aurochs and roc deer and the probable decline of forests and associated herbivores resulted in a general decrease in pressure on the vegetation from the native herbivorous fauna. ${ }^{66}$ Therefore, the role of creation and maintenance of open habitats in the forests of northern Portugal in which native herbivores played an important role before the Neolithic was replaced and enhanced by human activities such 
BRUNO PINTO, CARLOS AGUIAR AND MARIA PARTIDÁRIO

\section{From the Iron Age to the Middle Ages}

The proto-History of northern Portugal is characterised by successive invasions of Indo-European populations which came to the region since the second millennium вс. Although there is little information about the influence of these people, it is known that some of these immigrations had a significant impact on the vegetation of the region, such as the arrival of the Celts in the first half of the first millennium BC. ${ }^{68}$ However, considering that there was a cold period between 975 and $250 \mathrm{cal} \mathrm{BC}$, the decline in the arboreal vegetation in northwest Iberia during this period cannot be attributed exclusively to climatic changes or to the activities of these Indo-European people. ${ }^{69}$

At the end of the Bronze Age (i.e. transition to the first millennium BC), there is a systematic abandonment of open settlements in northern Portugal and an exclusive use of fortified settlements. ${ }^{70}$ Despite their heterogeneity, it is thought that most of the Iron Age people in this region depended on cattle raising, which was complemented by itinerant or semi-permanent agriculture and hunting and gathering. Considering that cattle raising implies extensive grazing lands, this certainly contributed to an increase in deforestation. The classical author Strabo describes these people as savages living in lands of poor soils, feeding essentially on cattle meat and oak acorns. The numerous stone statues of pigs and bulls in the northeast of Portugal dating from the pre-Roman and beginning of the Roman period, which served as stone marks in the landscape, reinforces the importance of cattle raising and grazing lands in this area."

The high number of fortified settlements found in northeast Portugal (more than 500) is indicative of significant demographic pressure on natural resources during this period. Since there was a judicious spatial distribution of their settlements, defensive structures with fortifications and the descriptions of pillage activities make it seem likely that there was intense competition over resources. ${ }^{72}$ Demographic pressure was increased by the use of iron tools and probably resulted in more efficient soil erosion and the destruction of forests, especially around settlements. There was also an intense exploitation of a wide range of vegetation from the Late Bronze Age to the Roman period, used as fuel, building material and food. According to descriptions of several classical authors, the mountains of northern Portugal were already deforested by the time of the Roman invasion. ${ }^{73}$

The conquest of the Portuguese territory by the Romans between the second and the first century $\mathrm{BC}$ brought drastic changes to agriculture. The Roman $p a x$, integration with a greater economic space, technical developments and demographic growth were factors which contributed to a general increase in asrimulture which was nrohahly also favoured he the Roman Warm Perind 
HISTORICAL ECOLOGY OF NORTHERN PORTUGAL

areas. Other factors such as the introduction of cultures like hard wheat and rye, the adoption of the system of polyculture, the use of agricultural rotations and organic fertilisers also had a major impact on land use. Considering that the traditional diet of the Romans consisted of cereals, wine, olives and, to a lesser extent, dry legumes and meat, Roman domination also implied a change to a more cereal-based diet, which was maintained in the Portuguese territory during subsequent centuries. ${ }^{75}$

Although the irregular terrain and ethnic diversity of northern Portugal contributed to a resistance to the beginning of the Roman domination, their implantation during more than five centuries had an impact on the human population in this region. In relation to the distribution of the population, an archaeological study in northeast Portugal showed that, from 246 proto-historic settlements, only 75 presented signs of romanisation and 151 new settlements were created during the Roman occupation. ${ }^{76}$ The reasons for these changes are related to the fact that Romans encouraged or forced local people to descend from the fortified settlements in mountains and to create new villages in accessible areas such as plains, which had more socio-economic opportunities. ${ }^{77}$ In conclusion, Roman domination had a major impact on the forests of the Portuguese territory. Major developments in agriculture promoted deforestation that was extended to the valleys. ${ }^{78}$ In this respect, it is interesting to note that romanisation and the fall of the Empire match peaks of decline and expansion, respectively, of arboreal vegetation in several palynological studies in NW Iberia. ${ }^{79}$

After the political instability of the third and fourth centuries, the disaggregation of the Roman Empire in the Portuguese territory in the beginning of the fifth century opened the way for Germanic domination between the fifth and eighth centuries, which brought pillage and general instability and motivated the reoccupation of the mountains and other less accessible places. These events contributed to the gradual degradation of the administrative organisation and agrarian exploitation systems of Roman times. The abandonment of many rural areas during this period resulted in a drastic reduction in agricultural production and animal husbandry, which is probably also related to the Dark Ages Cold Period (450-950 cal AD). This resulted in successive famines and epidemics, which took a toll on the human populations. Palynological information from Estrela Mountains (Central Portugal) shows an expansion of Betula alba, which indicates a recovery of the forest in this $\operatorname{arca}^{\mathrm{80}}$ (see Diagram 2). During the short periods of political stability, the economy of the region was probably based on animal husbandry, which was more important to the Germanic peoples than to Romans, associated with a semi-sedentary or shifting agriculture. ${ }^{81}$

The Muslim invasions in the beginning of the eighth century and the subse- 
BRUNO PINTO, CARLOS AGUIAR AND MARIA PARTIDÁRIO

invaded the area did not have the conditions to maintain their domination for long periods of time. The general insecurity of the populations, especially at the beginning and end of this historical period, promoted shifting agriculture, animal husbandry and hunting and gathering. This probably resulted in further forest recovery, which is indicated by the maintenance of Betula alba in the palynological diagram of Estrela Mountains ${ }^{82}$ (see Diagram 2).

According to Higounet (1966) in Williams (2000), the main forest areas in the Portuguese territory between the fifth and the eleventh centuries were located between the Tagus and Guadiana rivers (south of Portugal), whereas the north of this region had a smaller forest area. The explanation for this may be that there were was greater demographic pressure in northern Portugal before the Roman invasions. The definitive Christian Reconquest of this region by the Asturian kingdom in the eleventh century brought a relative political stability to this area, and migration and recolonisation, which resulted in population increase and the foundation of new settlements ${ }^{8.3}$ During the eleventh century, the promotion of agriculture which is attested by several documents resulted in the decline of the forests. In the palynological study of Estrela Mountains (central Portugal), there is a gradual decline of Quercus sp. and Betula alba in the Middle Ages, which is coincident with an increase in shrubland (Ericaceae sp.) and agricultural areas (Cerealia sp. ${ }^{84}$ (see Diagram 2). This information is coincident with the assumption that the growth of the agro-pastoral activities implied the deforestation of Portugal during the Middle Ages.

In relation to the fauna between the Iron Age and the Asturian invasions, an archaeological study about the Iron Age in the Aboboreira Mountains (NW Portugal) revealed the existence of bones of cervids and wild pig, whereas several historical paintings in the northeast of Portugal represent the hunting of red deer. ${ }^{85}$

The battles between the first Portuguese king and the king of Leon and Castilla over territories in the north of Portugal and Galicia (NW Spain) ${ }^{86}$ were gradually resolved in the twelfth century as the Christian Reconquest progressed to the south and, in the eighth century, frontier agreements with neighbours guaranteed long-term political stability to Portugal. In this century, the increasing population of this area preferred to settle valleys near rivers where the terrain was more suitable for agriculture, resulting in clearance of forests and swamps located in the valleys and the founding of new villages. ${ }^{87}$ The numerous letters of privilege conceded by the first kings of Portugal in this area were a clear incentive for the peopling of this region. In the area north of River Mondego, these forest clearances are mainly motivated by the creation of numerous monasteries, but also by several noble and military orders. These 


\section{HISTORICAL ECOLOGY OF NORTHERN PORTUGAL}

example, several villages of the Peneda-Gerês Mountains (NW Portugal) had an obligation to deliver large amounts of acorns and chestnuts and to raise pigs to offer to the king, which indicates that there were still significant areas of oak and chestnut trees in these mountains. ${ }^{88}$

Population growth and political stabilisation in northern Portugal after the Christian Reconquest, enhanced by the Medieval Warm Period in the twelfth and thirteenth centuries, resulted in a drastic increase in the rate of deforestation. Historical documents show frequent disputes over agricultural lands, which contributed to the occupation of marginal areas and increased soil erosion. This hypothesis is reinforced by the fact that there is a high increase in sediment release to the Portuguese coast in the twelfth century in the Aveiro region (Central Portugal) ${ }^{89}$ One of the factors which contributed to deforestation around cities and villages is that wood continued to be widely used by the increasing population as fuel, fertiliser and in the construction of houses and objects. In the twelfth century, there are records of wood exportation from northern Portugal to other European countries, which ceased in the thirteenth century. Moreover, this period is characterised by the growth in external maritime commerce and shipbuilding and the beginning of wood imports from Spain, France and England to the Oporto and Gaia ports (NW Portugal). The transition from exporter to importer of wood is probably related to the progressive scarcity of the forests in the region, which is reinforced by the fact that their community use since the tenth century was replaced in the thirteenth century by divisions of forests between neighbours and restrictions over cutting trees. Nevertheless, there were still extensive forests in northern Portugal during this period, especially in the mountains and monastery enclosures of the region. ${ }^{90}$

In relation to hunting between the eleventh and thirteenth centuries, species such as wild boar, wild rabbit, red deer, roe deer, brown bear (Ursus arctos) and wolf (Canis lupus) are commonly referred to in documents of the thirteenth century. Hunting was especially frequent in the mountain regions of northern Portugal, to satisfy the needs of the local populations but also to fulfil the rights that were due to the king. Wild rabbit was an important species, because its fur sustained the national pelt industry, and was one of the most exported Portuguese products. In the 'Law of the Price-Fixer' of 1253, the prices of several species of wild animals and birds and several restrictions for their capture are referred to, which suggests that they had significant economic importance."'

In a process similar to other European countries, population growth recorded in Portugal during the thirteenth century could no longer be supported by existing resources, which resulted in gradual food scarcity and an underfed population. Therefore, the end of the fourteenth and the fifteenth centuries were marked by 


\section{BRUNO PINTO, CARLOS AGUIAR AND MARIA PARTIDÁRIO}

of Black Plague. In the particular case of northern Portugal, in the inquiries of 1290 and 1321 the northeast is considered well populated, but has a reduced population in the census of 1422 . This idea of population scarcity is reinforced by complaints by the delegates of the king in 1439 about the low population of Trás-os-Montes region (NE Portugal), requests for the installation of shelters for outlaws and the privilege of reduced taxes. ${ }^{93}$

The general reduction in population led to the abandonment of agricultural fields during these two centuries and the decrease in forest clearances. Following a similar pattern to previous historical periods, the decrease in agriculture promoted once more an expansion in animal husbandry, which may have contributed to the increase of human-induced fires. Indeed, several authors suggest that these fires were very common in the fifteenth century, with the purpose of pasture renovation, coal production and even to capture wild rabbits. ${ }^{94}$

The wood scarcity in the larger settlements in the fifteenth century is evidenced by the complaints of the constant cutting of trees in the monastic enclosures in the Oporto region and the implementation of laws to maintain the remaining forest and to promote regulation of the exploitation, such as forbidding wood extraction, the prevention of human-induced fires, the creation of forest guards and the obligation to plant trees. During the mid-fifteenth century, the Portuguese Expansion continued to promote boat construction and this led to an increase in wood imports from other European countries. ${ }^{95}$ In the second half of this century, there was a recovery in the population density and an inherent increase in agricultural production; therefore this period is characterised by a new episode of intense deforestation, with the purpose of expanding areas destined for agriculture. This growth of agriculture also contributed to conflicts over space with animal husbandry, which tended to become once again more restricted over time. ${ }^{96}$

There were also special laws in the fourteenth and fifteenth centuries to protect hunting areas, in some cases with negative consequences for the local populations. This resulted in temporary authorisations to hunt species in problematic areas throughout the fourteenth and fifteenth centuries and in the popular representation to the king in 1371 against the increase of hunting grounds, due to the damage to agriculture caused by brown bear and wild boar. In the specific case of northern Portugal, there is a letter written by King D. Afonso V dated from 1466, in which he expresses his indignation over excessive hunting in this region and orders the people to stop hunting in the lands of the Crown and of other nobles. Moreover, the mountains of Peneda-Gerês (NE Portugal) had large numbers of hunting guards in the fifteenth century, which indicates that this area was commonly used as hunting ground. ${ }^{97}$ 
HISTORICAL ECOLOGY OF NORTHERN PORTUGAL

toponymic studies. The species was limited to the central west and northwest part of Portugal, and was already rare in the thirteenth century. Since the last known reference to this species is in an official document of 1446, it is likely that it became extinct in Portugal in the fifteenth or sixteenth centuries. ${ }^{96}$ There are also references to a small equid called 'zebro' (probably Equus hydruntinus or Equus hemionus) in the 'Law of the Price-Fixer', official documents and toponymic of both Portugal and Spain in the thirteenth and fourteenth centuries, which may have become extinct in the Iberian Peninsula around the fifteenth and sixteenth centuries, but this scarce evidence is not enough to confirm its former presence. ${ }^{99}$

The brown bear (Ursus arctos) is mentioned in the 'Law of the Price-Fixer' and other documents of the same period, but it seems likely that it became rare during the fourteenth or fifteenth century. The red squirrel (Sciurus vulgaris) also became rare and probably extinct during this period, due to extensive deforestation in the country. In the case of birds, there are references to the protection of species for hunting and falconry. ${ }^{100}$

The decline of several fauna species during the fourteenth and fifteenth centuries is probably related to the deforestation and hunting pressure which characterises most of the end of the Middle Ages in northern Portugal. However, it is too simplistic to attribute these events to human activities during these centuries. Instead, it seems more appropriate to consider these changes in the fauna as a consequence of a longer history of human intervention, in which the fourteenth and fifteenth centuries are the final chapters.

\section{From the sixteenth to the nineteenth centuries}

At the end of the fifteenth century, there was a demographic expansion in northern Portugal, which was to be maintained throughout the first half of the sixteenth century. In the last third of the 1500 s, the Portuguese people were affected by several episodes of famine and epidemics, probably related to inter-annual climatic instability associated with the Little Ice Age. ${ }^{101}$ The food crisis at the end of the sixteenth century was so severe in regions such as Trás-os-Montes (NW Portugal) that the king decided not to collect tax on the large amounts of cereals imported from abroad. In fact, one of the main motivations for the Portuguese discoveries was to find colonies with good conditions for wheat cultivation. In this scenario of a country with a food shortage and overseas expansion, the development of cattle-raising competed with agriculture, and was not favourable to forest clearance or to the increase of agricultural areas..$^{102}$

In relation to deforestation, there was wide use of wood in the Minho region 


\section{BRUNO PINTO, CARLOS AGUIAR ANI MARIA PARTIDÁRIO}

some cases this led to the limitation of one activity for the benefit of others. For example, in order to maintain the plantation of vineyards which required wood stakes, the Town Hall of Viana do Castelo (NW Portugal) limited the naval and civil industries in certain periods of the second half of the sixteenth century. During the fifteenth and the sixteenth centuries, deforestation reduced the size of the forests that still existed. According to a description from the mid-sixteenth century by João de Barros, the scarcity of trees was more acute in the northeast, whereas the northwest still had wooded areas. The explanation for this probably lies in soil and climate conditions, at least in the valleys, which are more favourable to the development of trees, and to forest resilience in the northwest. ${ }^{103}$

Although shipbuilding continued to have some impact on the deforestation of northern Portugal, this probably decreased in comparison with other uses of wood. The scarcity of wood justified the implementation of the Law of Trees in 1562 , which promoted the reforestation of uncultivated land or private properties. In the interior regions, reforestation of uncultivated lands competed with the exploitation of cattle, honey, shrubs and other products. Considering there were also inefficient enforcement mechanisms and little direction for the reforestation process, this law encountered local resistance and one of the ways to address this problem was to increase wood imports from abroad. ${ }^{104}$

Between the end of the sixteenth century and mid-seventeenth century, maize was introduced to Portugal as a new crop and became increasingly important to agriculture due to the fact that it took only a short time to mature, afforded greater production and could be grown in harmony with other crops and cattleraising. Nevertheless, the transition to the seventeenth century is characterised by food scarcity and a consequent decrease in population. Several authors refer to the excessive area of uncultivated lands as one of the reasons for the lack of cereals in the country. ${ }^{105}$ In fact, Portugal does not have good biophysical conditions for cereal cultivation, which would become clear in the twentieth century with the 'Wheat campaign'.

Descriptions of northern Portugal in documents from the seventeenth and eighteenth centuries refer to the cutting of trees, agricultural areas and the large stretches of uncultivated land, where extensive cattle-raising was practised.$^{106}$ The development of the Portuguese colonies during this period was detrimental to the reorganisation of the country, which is evident in the maintenance of a low population density in the interior of northern Portugal and also in the persistence of an agricultural model of subsistence. Despite the increase in agricultural production at the end of the seventeenth century, there continued to be a shortage of cereals throughout the eighteenth century, because the growth of 
HISTORICAL ECOLOGY OF NORTHERN PORTUGAL

The Ecclesiastical Inquiries of 1758 already describe the north of Portugal as a mostly deforested area. ${ }^{107}$

In the transition from the eighteenth to the nineteenth century, there are also several descriptions of Trás-os-Montes as a deforested region that was especially dedicated to agriculture and husbandry of cows and horses. ${ }^{108}$ According to the first reliable and detailed description by the Prussian botanist Count Hoffmannsegg, it is evident that this area was mostly deforested at the end of the $1700 \mathrm{~s}$, with occasional oak forests in steeper and more inaccessible areas. For example, this author wrote that 'In the area surrounding Vila Flor $[\ldots]$ the usual landscape is resumed. Cultivated fields in a territory without trees and full of rock outcrops which are unpleasant to see'. In the case of the Minho, the botanist described it as an agricultural area with dense population, with some pine and cork oaks in the coastal areas and oak forests mostly located in low and mid-altitude mountain areas. ${ }^{109}$ Other documents refer to the predominance of the chestnut trees and oaks in the interior of northern Portugal and plantations of pine trees in the more coastal regions. ${ }^{110}$

In the beginning of the nineteenth century, French invasions, civil wars and political convulsions had a negative effect on population, agriculture and animal husbandry, but the rest of this century is characterised by developments brought by the end of the Old Regime, modernisation of the country through the agricultural and industrial revolutions, and population growth. In 1834, the enclosures were abolished and the forest grounds surrounding convents and palaces become the only areas of forest protection in the country. In the second half of the nineteenth century, the agricultural area in northern Portugal increased significantly, which implied a reduction of uncultivated common land and the decline of animal husbandry. Nevertheless, some areas in northern Portugal such as Trás-os-Montes still had about half of their area occupied by uncultivated common land in the late nineteenth century, where animal husbandry prevailed." "Several authors continued to describe the general deforestation of northern Portugal and point to reforestation as the best solution to reduce the area of uncultivated common lands. ${ }^{112}$ In this respect, it is curious to notice that most of the wood used in the construction of the Portuguese railway was imported from abroad, with occasional exceptions for wood extracted in the centre and south of the country. ${ }^{113}$ Growth of knowledge about forestry, the creation of the Forestry Services and afforestation, mainly with Pinus pinaster, of Peneda-Gerês and Estrela mountains marks the evolution of the vegetation in northern Portugal at the end of the nineteenth century. ${ }^{14}$

In relation to the fauna between the sixteenth and the nineteenth century, since Lisbon and the nearby cities were the new political centres of the country, 


\section{BRUNO PINTO, CARLOS AGUIAR AND MARIA PARTIDÁRIO}

D. João $\mathrm{V}$ imposed the death penalty on individuals caught hunting in enclosures. The abolition of enclosures in 1834 implied the abolition of the fauna protection in these areas. ${ }^{116}$

The brown bear was already rare in the fourteenth and fifteenth centuries and probably became extinct when the last individual was shot in the PenedaGerês Mountains in 1650. The wild goat (Capra pyrenaica) also existed in northern Portugal until the end of the nineteenth century and probably became extinct with the capture of the last individual in the Peneda-Gerês Mountains in 1890. Several descriptions of the fauna in the seventeenth and the eighteenth centuries mention red deer, roe deer and wild boar as common species in this area. However, there was a decline of red deer and, to a lesser extent, of roe deer and wild boar since the end of the eighteenth century. ${ }^{117}$ At the end of the nineteenth century, the red deer was considered extinct in northern Portugal and roe deer only persisted in the Peneda-Gerês Mountains. In the case of birds, a document of 1744 confirms the existence of capercaillie (Tetrao urogallus) in the Peneda-Gerês Mountains, which is supported by frequent references to this species in toponyms of this area. This species probably became extinct in the eighteenth or nineteenth century. ${ }^{118}$

\section{From the twentieth century to the present}

Demography in northern Portugal during the twentieth century is characterised by an almost constant migration from rural areas to the major cities of the coastal areas, and abroad, motivated by the search for employment and better living conditions. The consequences of this migration were the abandonment of agriculture, which in some cases increased the conversion of agricultural land into forest. ${ }^{119}$ In the transition to the twentieth century, there was extensive topographical work, motivated by the publication of the first national map of agriculture and forestry in 1910. According to this map, northern Portugal had a low percentage of native forest, which was mostly located in more inaccessible areas such as steep hills along the waterways. ${ }^{120}$ This period of transition is also characterised by increasing afforestation, which was mainly directed to uncultivated common lands in the mountains.

At the end of the 1920s, there was an increase in afforestation, which was stimulated by the export of pine wood to England and the development of Portuguese industry. However, the solution to the problem of uncultivated land was still a key point of discussion between economists, agronomists and silviculturalists. The idea of an agricultural country prevailed and the 'Wheat campaign' was implemented. In the north of Portugal, the desire for self-suficiency in cereals 
HISTORICAL ECOLOGY OF NORTHERN PORTUGAL

uncultivated land was also implemented from 1938 to 1995 and had its greatest influence in the mountains of northern Portugal. ${ }^{21}$

The change from an agricultural and cattle-raising society to an urban society implied a reduction of agricultural workers and activities with consequences for the vegetation. For example, there was an increase in fuel accumulation in forested areas and, consequently, an increase in the number of fires, which is still a serious concern today. This abandonment is still one of the more influential factors regarding the vegetation in northern Portugal, since the shrubland area has increased significantly in the last decades. There is also a continuous, but very slow, expansion of native forest. However, succession is often blocked (at the human scale), which means that the resilience of the shrubland and human-induced fire keep these areas covered with pyrophite shrublands (i.e. shrub encroachment).

In relation to the fauna, the first half of the twentieth century is characterised by a change of focus from species which became locally extinct or rare in northern Portugal, such as red deer and roe deer, to more common species such as wild rabbit and red partridge. ${ }^{122}$ Interest in these species was probably motivated by the scarcity of larger herbivores, but also due to their probable increase related to the 'Wheat campaign' previously mentioned.

The creation of specific protection laws, Protected Areas and agricultural abandonment contributed to halting the decline of species such as the wolf. In the case of the wild rabbit, a keystone species to this area, diseases such as myxomatosis and HVD, habitat destruction and intense hunting pressure have contributed to its general low density in the north of Portugal. ${ }^{123}$ However, there are also cases of species, such as red squirrel, red deer and wild goat, which have expanded their distribution from northwest Spain and were re-established in northern Portugal in the 1980s and 1990s. Although the abundance and distribution of red deer and wild goat are still very limited at present, this is a positive sign for the future. In the case of birds, the presence of the grey partridge (Perdix perdix) is well documented in the high lands of north Portugal, but it probably became rare in the first half of the twentieth century and extinct in the region between the 1950s and the 1960s. It is likely that the bearded vulture (Gypaetus barbatus) and crane (Grus grus) which occupied the north of Portugal became regionally extinct during the twentieth century. The golden eagle (Aquila chrysaetus) also decreased until the mid-twentieth century, occurring today in very low density in this area. ${ }^{124}$ 


\section{BRUNO PINTO, CARLOS AGUIAR AND MARIA PARTIDÁRIO}

TABLE 1 (continues on facing page).

\begin{tabular}{lll}
\hline Chronology & Beginning of period & Human impact on natural resources \\
\hline $\begin{array}{l}\text { Transition to the } \\
\text { Holocene }\end{array}$ & $\begin{array}{l}16,000 \mathrm{yr} \mathrm{BP} \\
\text { (ie. } \mathrm{XV} \text { mil. } \mathrm{BC} \text { ) }\end{array}$ & Hunting and gathering. \\
\end{tabular}

\begin{tabular}{lll}
\hline Mesolithic & $\begin{array}{l}10,000 \mathrm{yr} \text { BP } \\
\text { (i.e. IX mil. BC) }\end{array}$ & $\begin{array}{l}\text { Hunting and gathering activities probably centred } \\
\text { in coastal and fluvial areas. Small-scale human } \\
\text { deforestations. }\end{array}$
\end{tabular}

Neolithic Late VI/Early V $\quad$ Beginning of agro-pastoral way of life.

millennium $B C$

$\overline{\text { Bronze Age } \quad \text { Early III millennium BC Intensification of agriculture and animal husbandry. }}$

\begin{tabular}{lll}
\hline Iron Age $\quad$ Early I millennium BC & $\begin{array}{l}\text { Invasions of Indo-European people, with reduction } \\
\text { of agriculture and increase of animal husbandry. }\end{array}$
\end{tabular}

\begin{tabular}{lll}
\hline Roman period & $\mathrm{II} / \mathrm{I}$ century $\mathrm{BC}$ & $\begin{array}{l}\text { Roman invasion, with large-scale expansion of } \\
\text { agriculture and demographic increase. }\end{array}$
\end{tabular}

\begin{tabular}{lll}
\hline German period & Early V century AD & $\begin{array}{l}\text { German invasion, with frequent episodes of pillage } \\
\text { and wars; demographic decrease. }\end{array}$ \\
\hline Muslim period & Early VIII century AD & $\begin{array}{l}\text { Muslim invasion, with reduced presence after mid } \\
\text { VIII century; scarce population. }\end{array}$ \\
\hline Medieval period & Early XI century AD & $\begin{array}{l}\text { Christian Reconquest, increased farming and } \\
\text { demographic growth until XIII century. Successive } \\
\text { famines and plagues since the mid-XIV century } \\
\text { and demographic recovery after mid-XV century. }\end{array}$ \\
\hline Modern Period & XVI century AD & $\begin{array}{l}\text { Cycles of demographic grovth and reduction; } \\
\text { expansion of agriculture to marginal lands. }\end{array}$
\end{tabular}

\begin{tabular}{|c|c|c|}
\hline $\begin{array}{l}\text { Contemporary } \\
\text { Period }\end{array}$ & $\mathrm{XX}$ century $\mathrm{AD}$ & $\begin{array}{l}\text { 'Wheat campaign' and afforestation with exotic } \\
\text { species in uncultivated lands; generalisation of the } \\
\text { moderrisation of agriculture; rural exodus to the } \\
\text { major cities. }\end{array}$ \\
\hline
\end{tabular}


HISTORICAL ECOLOGY OF NORTHERN PORTUGAL

TABLE 1 (continued from facing page)..

\begin{tabular}{|c|c|c|}
\hline Main vegetation changes & Main fauna changes & Main climate changes \\
\hline $\begin{array}{l}\text { Expansion of the forest (first, } \\
\text { Betula sp., followed by Pinus } \\
\text { sp., replaced later by Quercus } \\
\text { sp.) and decline of steppe } \\
\text { vegetation. }\end{array}$ & $\begin{array}{l}\text { Decline of alpine species and } \\
\text { colonisation of woodland- } \\
\text { adapted species }\end{array}$ & Climate warming \\
\hline $\begin{array}{l}\text { Gradual domination of Quercus } \\
\text { sp. forests, with decline of Pinus } \\
\text { sp. to higher altitudes; Mosaic } \\
\text { of closed and open vegetation. }\end{array}$ & $\begin{array}{l}\text { Decline of aurochs and wild } \\
\text { horse. }\end{array}$ & $\begin{array}{l}\text { Climate warming } \\
\text { Anathermic phase } \\
(10,000-7,500 \mathrm{yr} \mathrm{BP})\end{array}$ \\
\hline $\begin{array}{l}\text { Forest decline due to } \\
\text { deforestation for agro-pastoral } \\
\text { activities, which started around } \\
\text { mid-IV millennium BC. }\end{array}$ & Aurochs becomes extinct & $\begin{array}{l}\text { Temperature and } \\
\text { humidity reached a peak. } \\
\text { Climatic Optimum } \\
(7,500-2,500 \text { yr BP })\end{array}$ \\
\hline $\begin{array}{l}\text { Large-scale forest decline in the } \\
\text { II millennium } \mathrm{BC} \text {. }\end{array}$ & $\begin{array}{l}\text { Wild horse becomes extinct; } \\
\text { probable decline of forest } \\
\text { species. }\end{array}$ & $\begin{array}{l}\text { Temperature and } \\
\text { humidity reached a peak. } \\
\text { Climatic Optimum } \\
(7,500-2,500 \text { yr BP) }\end{array}$ \\
\hline $\begin{array}{l}\text { Forest decline, probably due to } \\
\text { both climate change and actions } \\
\text { of the Indo-European people. }\end{array}$ & & $\begin{array}{l}\text { First Cold Period of the } \\
\text { Subatlantic } \\
(975 \text { to } 250 \text { cal. BC) }\end{array}$ \\
\hline $\begin{array}{l}\text { Expansion of deforestation to } \\
\text { the valleys, with clearance of } \\
\text { forest and swamp areas. }\end{array}$ & & $\begin{array}{l}\text { Roman Warm Period } \\
(250 \mathrm{cal} \mathrm{BC} \text { to } 450 \mathrm{cal} \mathrm{AD})\end{array}$ \\
\hline Forest recovery. & & $\begin{array}{l}\text { Dark Ages Cold Period } \\
(450 \text { to } 950 \mathrm{cal} \mathrm{AD})\end{array}$ \\
\hline Continuation of forest recovery. & & $\begin{array}{l}\text { Dark Ages Cold Period } \\
(450 \text { to } 950 \mathrm{cal} \mathrm{AD})\end{array}$ \\
\hline $\begin{array}{l}\text { Forest decline and expansion } \\
\text { of agricultural and uncultivated } \\
\text { areas. }\end{array}$ & $\begin{array}{l}\text { Extinction of beaver, red squirrel } \\
\text { and possibly a small equid }\end{array}$ & $\begin{array}{l}\text { Medieval Warm Period } \\
\text { ( } 950 \text { to } 1400 \mathrm{cal} \text { AD) } \\
\text { Little Ice Age } \\
\text { (1400 to } 1850 \mathrm{cal} . \mathrm{AD}) \\
\end{array}$ \\
\hline $\begin{array}{l}\text { Forest decline and maintenance } \\
\text { of agricultural and uncultivated } \\
\text { areas. }\end{array}$ & $\begin{array}{l}\text { Extinction of brown bear, } \\
\text { capercaillie, wild goat and red } \\
\text { deer; decline of roe deer and } \\
\text { wild boar. }\end{array}$ & $\begin{array}{l}\text { Little Ice Age } \\
\text { (1400 to } 1850 \mathrm{cal} . \text { AD) }\end{array}$ \\
\hline $\begin{array}{l}\text { Shrub encroachment, slow } \\
\text { forest recovery and growth of } \\
\text { industrial afforestation }\end{array}$ & $\begin{array}{l}\text { Extinction of grey partridge } \\
\text { and decline of wild rabbit; Re- } \\
\text { establishment of wild goat, red } \\
\text { squirrel and red deer and recent }\end{array}$ & $\begin{array}{l}\text { Recent warming } \\
\text { (since } 1850 \mathrm{cal} A \mathrm{AD} \text { ) }\end{array}$ \\
\hline
\end{tabular}


BRUNO PINTO, CARLOS AGUIAR AND MARIA PARTIDÁRIO

\section{DISCUSSION}

The ecological and historical information about the deforestation process from the Neolithic onwards supports the idea of a spatial differentiation in northern Portugal, beginning on the high plateaus of this region and extending later to the valley areas. This development of deforestation seems to be associated with changes of social systems (e.g. increase of sedentarisation with the location of communities in areas of mid-mountain), greater integration of agro-pastoral activities, development of tools and techniques which caused erosion of deeper soils, and possibly climatic change (higher climatic irregularity increases agricultural risks on the high plateaus and promotes agriculture in the valleys, where the temperature is more temperate).

These changes in the vegetation of northern Portugal during the Holocene follow the model suggested by Boserup (1965) of an increase (which can be intermittent) of the area and intensity of agro-pastoral use of the land over time due to population growth. Despite the limited information in this area, there is a general trend of forest decline after the Neolithic, which is interspersed with periods of recovery of the vegetation related to decrease of human pressure on natural resources. ${ }^{125}$ For example, it is known that the political-administrative instability and the reduction of human population during the Germanic domination of this area between the fifth and eighth centuries enabled forest recovery, which was probably extended to the period of conflict between Muslims and Christians.

In relation to the influence of climate on the vegetation, the expansion of the forest in the transition to the Holocene and during the Mesolithic and Neolithic is related to the climate warming which was registered during these periods. Between the Late Bronze Age and the Roman periods, human action seems to become the most important factor determining the vegetation in this area, although the climate continued to have direct and indirect influences. For example, the colder periods of the German, Muslim and late Medieval periods seem to be associated with food reduction, demographic decrease and political instability. ${ }^{126} \mathrm{~A}$ recent study by Dinis et al. (2006) about sediment deposition in three lagoons of Central Portugal also concluded that anthropogenic action was the most important factor determining the vegetation in the last 5000 years. The authors also mention that there is a relationship between social development and climatic trends, which shows that climate continued to play a role in the deforestation of this area. On the other hand, Desprat et al. (2003) have argued that the forest reduction near the Ria de Vigo (south Galicia, NW Spain), since 975 cal BC suggests climate as the main cause rather than anthropogenic 
HISTORICAL ECOLOGY OF NORTHERN PORTUGAL

reinforces the direct effect that the climate continued to have on the vegetation until the present.

In terms of fauna, the natural herbivores were probably reduced with the extinction of species such as wild horse, aurochs and European beaver. Considering the long periods of decline of the forests in the area, it seems likely that the changes brought by agro-pastoral societies resulted in a reduction of woodland species and an increase in species which prefer open habitats. In some cases, forest decline seems to be the main cause of species extinctions, such as of brown bear, red squirrel and capercaillie. In other cases, such as the extinctions of wild goat, red deer and grey partridge, the main cause was probably excessive hunting. The recent trend is for the recovery of the fauna, which seem to have benefited from the creation of Protected Areas, specific protection laws and the expansion of species from northwestern Spain.

Based on these vegetation and fauna changes, it is possible to argue for a 'long-term ecological transformation' of northern Portugal during the Holocene. ${ }^{127}$ In the beginning of the Holocene, climate seems to have been the most important trigger of change in this area, but human impact probably became preponderant in the last 5000 years. Nevertheless, the climate continued to have a significant direct and indirect role in these changes, influencing factors such as the rhythm of forest growth and demography. According to several authors, positive and negative feedback cycles between human actions and natural systems kept the Mediterranean ecosystems resilient and may have, to some extent, replaced natural disturbance regimes such as fires, herbivory, wind-throws and landslides. ${ }^{128}$ In this process, ecosystems flipped into new alternative stable states, in order to incorporate the decrease of natural disturbance and the increase of human-induced disturbance. However, the transition from mature oak forest to the early-to mid-successional vegetation which is common in present landscapes, and the extinction of fauna species, implied the loss of ecological functions which were not fully compensated by human-induced actions. ${ }^{129}$ For example, the European beaver is generally considered a keystone species, because their browsing and damming activities induce significant alteration in the structure and composition of the habitats where they live. ${ }^{130}$ Such modifications were lost after the extinction of this species in the fifteenth century, and were not replaced by the domestic herbivores present in the area.

Despite these arguments in favour of the loss of ecological function during the Holocene, it is acknowledged that the Mediterranean area maintains a high resilience to anthropogenic impact. In accordance to what happens in other Mediterranean regions, the vegetation and the fauna of northern Portugal have been slowly recovering in recent decades, which is reflected in the gradual recovery 


\section{BRUNO PINTO, CARLOS AGUIAR AND MARIA PARTIDÁRIO}

domestic animals is an efficient form of controlling shrub encroachment, thus increasing the mosaic of habitats which are known to benefit biodiversity.

This characteristic of high resilience has also been recently attributed by Butzer (2005) to human communities which have lived in the Mediterranean region for millennia. In the case of northern Portugal, ethnographic and historical information concerning villages in the mountain ranges also reveals several trends that can be interpreted as socio-economical adaptations to limited natural resources. For example, the communitary organisation which was present in many villages increased the efficiency of activities such as cattle-raising and limited grazing and/or agricultural pressure on community lands. These populations also promoted birth control through the traditions of marrying only one of the siblings, late marriage, sexual abstinence and traditional methods of fertility control. For example, in the village of Rio de Onor (NE Portugal), the number of people was relatively stable, at least, between 1796 and 1911. Following the external influence of young men returning from World War One there was increasing disrespect for these traditions, which led to an increase in the number of people during the subsequent years and promoted socio-economic disequilibrium. Other strategies to avoid overexploitation of natural resources in this region include the use of alternative sources of income and periods of massive emigration. ${ }^{133}$

In conclusion, the environmental history of northern Portugal confirms a longterm impact of both natural and human-induced changes that characterises the Mediterranean region, in which anthropogenic influence became the main factor in the last 5000 years. In the transformation of the ecosystems, they probably flipped through alternative stable states in order to incorporate an increase in human action and a decrease in natural disturbance which implied a significant loss of ecological function. Nevertheless, the high resilience of ecosystems has enabled their sustainability over eight millennia and has allowed a recovery of the vegetation and fauna during recent decades.

\section{NOTES}

We are grateful to Dr. Simon Davis and to Dr. Pim van der Knaap for their contributions to this article. This study was funded by the Portuguese Foundation for Science and Technology.

'e.g. Blondel and Aronson 1999; Blondel 2006.

${ }^{2}$ Naveh and Carmel 2003. 
HISTORICAL ECOLOGY OF NORTHERN PORTUGAL

${ }^{7}$ Costa et al. 1998.

${ }^{8}$ Mesquita 2005.

${ }^{9}$ Agroconsultores and COBA 1991.

"10 Naveh and Leiberman 1990.

"INE 2005.

${ }^{12}$ Ramil-Rego et al. 1998.

${ }^{13}$ Allen et al. 1996.

${ }^{14}$ van der Knaap and van Leeuven 1995, 1997.

${ }^{15}$ Sanches 1997; Lemos 1993, 1997.

${ }^{16}$ e.g. Link 1803.

${ }^{17}$ e.g. Leão 1735.

${ }^{18}$ e.g. Devy-Vareta 1985, 1986; Radich and Alves 2000.

${ }^{19}$ e.g. Pinheiro 1987.

${ }^{20}$ e.g. Catry 1999; Cabral et al. 2005; Dias 1948, 1953.

${ }^{21}$ Guerreiro 1981; Ruddiman and MacIntyre 1981.

${ }^{22}$ Coudé-Gaussen 1981; Coudé-Gaussen and Denèfle 1980.

${ }^{23}$ Allen et al. 1996.

${ }^{24}$ Muñoz-Sobrino et al. 2004; Ramil-Rego et al. 1996 a,b; Cardoso 2002.

${ }^{25}$ Zilhão 1997, 2003.

${ }_{26}^{26}$ Cardoso 2002; Zilhão 2003.

${ }^{27}$ Mendes, 1968; Vasconcelos 1980.

${ }^{28}$ Antunes 1993; Araújo 2000; Burke et al. 2003.

${ }^{29}$ Baptista and Gomes 1995; Aura et al. 1998.

${ }^{30}$ e.g. Aura et al. 1998.

${ }^{31}$ Antunes 1993; Barnosky et al. 2004; Burney and Flannery 2005.

${ }^{32}$ Muñoz-Sobrino et al. 2004, 2005; Allen et al. 1996; Ramil-Rego et al. 1998; van der Knaap and van Leeuwen 1995,1997; Mateus 1992.

${ }^{33}$ Honrado 2003; Figueiral 1995; Figueiral and Carcaillet 2005.

${ }^{34}$ Zilhão 1993, 2000; Aura et al. 1998.

${ }^{35}$ Davis 2005.

${ }^{36}$ Zilhão 2000; Cardoso 2002.

${ }^{37}$ Muñoz-Sobrino et al. 2005; Araújo 2000; Bicho 1994.

${ }^{38}$ Blanco et al. 1997; Muñoz-Sobrino et al. 2005; Brown 1997; Araújo 2000.

${ }^{39}$ Grove and Rackham 2001.

40) Vera 2000.

${ }^{41}$ van der Knaap and van Leeuwen 1995,1997.

${ }^{42}$ Zilhão 1993, 2000. 
32

\section{BRUNO PINTO, CARLOS AGUIAR AND MARIA PARTIDÁRIO}

${ }^{47}$ e.g. Grove and Rackham 2001.

${ }^{48}$ Jorge 1990.

${ }^{49}$ Muñoz-Sobrino et al. 1996.

${ }^{50}$ van der Knaap and van Leeuwen 1995.

${ }^{51}$ Muñoz-Sobrino et al. 2004; Allen et al. 1996; Ramil-Rego et al. 1998.

52 Cardoso 2002; Diamond 1997; Sanches 1996.

${ }^{53}$ Sanches 1997; Figueiral and Sanches 2003.

${ }^{54}$ Sanches 1996; Jorge 1990.

${ }^{55}$ Bettencourt 1995; Figueiral and Sanches 2003; Diamond 1997.

${ }^{56}$ Figueiral and Sanches 2003.

${ }^{57}$ Carcaillet et al. 2002.

${ }^{5 k}$ Cortazar 1988.

${ }^{59}$ Jorge 1990.

${ }^{60}$ Figueiral and Sanches 2003; Figueiral and Bettencourt 2004; Jorge 1988.

${ }^{61}$ Lautensach 1988, 1989.

${ }^{62}$ Jorge 1990.

${ }^{63}$ Cardoso 2002.

${ }^{64}$ Monteiro-Rodrigues 2000, 2002; Valente 2004.

${ }^{65}$ Antunes 1993; Cardoso 2002; Levine 1999.

${ }^{66}$ Gordon et al. 2004; Pykala 2000.

${ }^{67}$ Bengtsson et al. 2000: Naveh and Carmel 2003; Grove and Rackham 2001; Perevolotsky and Seligman 1999.

${ }_{68}^{68}$ Fabião 1992; Lautensach 1988, 1989.

${ }^{69}$ Ruiz-Zapata et al. 1995.

${ }^{70}$ Martins 1997; Lemos 1997.

${ }^{71}$ Fabião 1992; Cardoso 1994,1997; Lemos 1997; Alvarez-Sanchis 2000.

${ }^{72}$ Silva and Gomes 1994; Lemos 1997; Cardoso 1994; Jorge 1990.

${ }_{73}$ Martins 1997; Oubiña 2003; Figueiral 1996; Lautensach 1989; Cardoso 1994, 1997; Guerra 1995; Figueiral 1996.

${ }^{74}$ Martins 1997; Lautensach 1988, 1989.

${ }^{75}$ Fabião 1992; Alarcão 1987.

${ }^{76}$ Fabião 1992; Alarcão 1987; Lemos 1993.

T7 Alarcão 1987.

${ }^{78}$ Leguay 1993; Fabião 1992, Lautensach 1988, 1989.

79. Ramil-Rego et al. 1996 a,b.

"su Mattoso 1992a; Fabião 2004, Lautensach 1988, 1989; Leguay 1993; Trindade 1981.

${ }^{81}$ Mattoso 1992b; Beirante 1993. 


\section{HISTORICAL ECOLOGY OF NORTHERN PORTUGAL}

${ }^{86}$ In the beginning of the XII century, the Muslim geographer Idris described northern Portugal as a flourishing region. with many agricultural fields and a population scattered in isolated houses, villages, fortified-places and castles. This author also states that this area had many warriors, either on foot or riding horses (Coelho 2004).

${ }^{87}$ Coelho 2004; Mattoso 1993; Andrade 1994. 1997; Maurício, 1997; Taborda 1932; Devy-Vareta and Alves, 2007.

${ }^{88}$ Maurício 1997; Andrade 1994, 1997; Beirante 1993; Trindade 1981; Almeida 1978; Fernandes 2004.

${ }^{89}$ Abecassis 1955 in Dinis et al. 2006.

${ }^{90}$ Devy-Vareta 1985, 1986; Almeida 1978.

${ }^{91}$ Maurício 1997; Andrade 1994; Almeida 1978; Aristides and Abílio 1988.

${ }^{92}$ Sousa 1993.

${ }^{93}$ Magalhães 1993; Sousa 1993: Alves 1983; Lobo 1903; Trindade 1981. The causes for this depopulation in the interior regions of Portugal can be attributed to the demographic crisis of the XIV century, the migration of the population to the cities of the coastal areas and the pillage during the wars against Castilla.

${ }^{94}$ Fernandes 2004; Sousa 1993; Lobo 1903.

${ }^{25}$ Devy-Vareta 1985, 1986: Lobo 1903; Bacta Neves 1980.

${ }^{*}$ Silva and Hespanha 1993: Dias 1998: Fernandes 2004: Sousa 1993; Oliveira Marques 1986.

${ }^{97}$ Oliveira Marques 1986; Bacta Neves 1967; Almaça 2000); Lobo 1903.

${ }^{98}$ Antunes et al. 1989, Antunes 1993; Almaça 2000.

"Aristides and Abílio 1988; Almaça 2000; Antunes et al. 1989, Antunes 1993, Simon Davis pers. comm.

${ }^{100}$ Antunes 1993: Almaça 2000.

${ }^{101}$ Mattoso 1992 a.b; Dias 1998.

102 Silva and Hespanha 1993: Dias 1998; Serrão 1993; Alves 1983; Ferrão 1992.

${ }^{103}$ Dias 1998: Serrão 1993; Silva and Hespanha 1993; Devy-Vareta 1986: Barros 1919.

${ }^{104}$ Costa 1993; Devy-Vareta 1986; Rego 2001; Boxer 1977; Silva and Hespanha 1993; Dias 1998.

${ }^{105}$ Devy-Vareta 1986; Rebello da Silva 1869.

${ }^{106}$ Devy-Vareta and Alves 2007.

${ }^{107}$ Menezes 2001: Pinto et al. 2001 ; Serrão 1993.

${ }^{198}$ Mendes 1995; Menezes 2001; Link 1803; Oliveira and Costa 1996.

${ }^{109}$ Ferreira 1994; Link 1803.

${ }^{110}$ Pereira 1910; Amorim 1973; Taborda 1932: Link 1803; Ferreira 1994; Barros 1919; Mendes 1968. 


\section{BRUNO PINTO, CARLOS AGUIAR AND MARIA PARTIDÁRIO}

114 Rego 2001.

${ }^{115}$ Alves 1983.

${ }^{116}$ Rego 2001.

117 Baeta Neves 1968; Vasconcelos 1980; Antunes 1993; Vasconcelos 1980; Costa 1706; Ferreira 1994; Leal 1875; Balbi 1822.

${ }^{118}$ Pimenta and Santarém 1996; Catry 1999; Dobson 1998; Mendes 1968.

${ }^{119}$ Rosas 1994; Radich and Alves 2000.

${ }^{120}$ Direcção Geral Agricultura 1910. For example, in the Peneda-Gerês (NW) and Montesinho (NE) mountains, most of these areas were occupied by uncultivated common land and, to a lesser extent, by tree cultures, whereas the native forest only represented approximately ten percent of the total area.

${ }^{121}$ The effects of such actions in the northeast of Portugal are well exposed by the Abbot of Baçal: "there are remains of beautiful oak forests [...] that the ignorant people are destroying with iron and fire, without realising that the cereal produced in the areas of forest clearance will soon stop, conducing to a rapid and absolute sterility'. Rego 2001; Maurício 1997; Radich and Alves 2000.

122 Dias 1948, 1953.

${ }^{123}$ Castro and Palma 1996.

${ }^{124}$ Cabral et al. 2005; Catry 1999; Pimenta and Santarém 1996.

${ }^{125}$ Boserup 1965; Perevolotsky and Seligman 1999; Butzer 2005.

${ }^{126}$ e.g. Butzer 2005.

${ }^{127}$ Butzer 2005.

${ }^{128}$ Blondel and Aronson 1999; Blondel 2006; Bengtsson et. al. 2000.

${ }^{129}$ Westra et al. 2000; Kay 2000; Maurer 1999.

${ }^{130}$ Donkor and Fryxell 1999; Nolet and Rosell 1998; Gurnell 1998.

${ }^{131}$ Grove and Rackham 2001.

${ }^{132} \mathrm{c}$. g. Blondel and Aronson 1999; Blondel 2006; Bengtsson et. al. 2000.

${ }^{133}$ Dias 1948, 1953; Guerreiro 1981; Mendes 1995.

\section{BIBLIOGRAPHY}

Agroconsultores and COBA 1991. Carta dos Solos, Carta do Uso Actual da Terra e Carta da Aptidão da Terra do Nordeste de Portugal. Vila-Real: UTAD, PDRITM.

Alarcão, J. 1987. Portugal Romano. Verbo.

Allen.J.R.M.,B.Huntley and W.A. Watts. 1996. 'The vegetation and climate of northwest Iberia over the last 14000 years'. Journal of Quaternary Science 11(2): 125-147.

Almaça, C. 2000. O homem Medieval e a biodiversidade. Museu Bocage. Lisbon: Museu 


\section{HISTORICAL ECOLOGY OF NORTHERN PORTUGAL}

Alvarez-Sanchís, J.R. 2000. 'The Iron Age in Western Spain (800 DC-AD50): An overview'. Oxford Journal of Archaeology 19(1): 65-89.

Amorim, M.N. 1973. Rebordãos e a sua População. Lisbon: Imprensa Nacional-Casa da Moeda.

Andrade,A: A.1994. Vilas, poder régio e fronteira: o exemplo do Entre Lima e Minho Medieval. Lisbon: Faculdade ciências sociais e humanas. Universidade Nova Lisboa.

Andrade, A: A. 1997. O Entre Lima e Minho no Séc. XIII: a Revelação de uma Região. Câmara Municipal Arcos Valdevez.

Antunes, M.T.,E.Crespo,P.Mein,J.Pais and J.P.Teixeira. 1989. 'Guia (Algerve) gisement de vertébrés quaternaires à caractère saisonnier'. Ciências da Terra 10: 97-106.

Antunes, M.T. 1993. 'Mamíferos em Portugal. Extinções desde o Plistocénico Superior'. Liberne 43/44: 6-10.

Aristides, P. and R. Abílio. 1988. Lei da Almotaçaria. 26 de Dezembro de 1253. Banco Pinto and Sotto Mayor.

Araújo, A.C 2000. 'Long term change in Portuguese early Holocene settlement and subsistence'. In Mesolithic on the Move. Papers presented at the Sixth International Conference on the Mesolithic in Europe, ed. L. Larsson, H. Kindgren, D. Loeffler and A. Akerlund (Stockholm), pp. 569-586.

Aura, J.E., V. Villaverde, M.G. Morales, C.G. Sainz, J. Zilhão and L.G. Strauss. 1998. 'The Pleistocene-Holocene transition in the Iberian Peninsula: continuity and change in human adaptations'. Quaternary International 49/50: 87-103.

Baeta Neves, C.M. 1967. Sobre a existência e extinção do urso em Portugal. Liga para Proteç̧ão da Natureza.

Baeta Neves, C.M. 1980. História Florestal, Aquícola e Cinegética. Vol. 1-5. Ministério da Agricultura e Pescas. Direcção Geral do Ordenamento e Gestão Florestal.

Balbi, A. 1822. Essai statistique sur le royaume de Portugal et d'Algarve. Lisbon: Imprensa Nacional-Casa da Moeda.

Baptista, A.M. and M.V. Gomes. 1995. 'A arte do vale do Côa, resultados dos primeiros trabalhos'. Férvedes 2: 143-149.

Barnosky, A.D., P.L. Koch, R.S. Feranec, S.L. Wing and A.B. Shabel. 2004. 'Assessing the causes of Late Pleistocene extinctions on the continents'. Science 306: 70-75.

Barros, J. 1919. Geographia d'entre Douro e Minho e Trás-os-Montes. Oporto: Câmara Municipal Porto.

Beirante, M.A. 1993. 'A Reconquista Cristã'. In Nova História de Portuga, ed. J. Serrão and A.H. Oliveira Marques, Vol. 2: 253-376. Presença.

Bengtsson, J., S.G. Nilsson, A. Franc and P. Menozzi. 2000. 'Biodiversity, disturbances, ecosystem function and management of European forests'. Forest Ecology and Management 132: 39-50.

Bettencourt, A.M.S. 1995. 'Dos inícios aos finais da Idade do Bronze no norte de Portugal' In A Idade do Bronze em Portusal: discursos de noder ed S A Inroe Institutn 


\section{BRUNO PINTO, CARLOS AGUIAR AND MARIA PARTIDÁRIO}

Blanco, E., M.A. Casado, M. Costa, R. Escribano, M. García, M. Génova, A. Gómez, F. Gómez, J.C. Moreno, C. Morla, P. Regato and H. Saínz. 1997. Los Bosques Ibéricos. Interpretación geobotánica. Barcelona: Editorial Plancta.

Blondel, J. 2006. 'The design of Mediterranean landscapes: A millennial story of humans and ecological systems during the Historic Period'..Human Ecology 34(5): 713-729.

Blondel, J. and J. Aronson. 1999. Biology and Wildlife of the Mediterranean Region. Oxford: Oxford University Press.

Boserup, E. 1965. The Conditions of Agricultural Growth: The Economics of Agrarian Change under Population Pressure. Chicago: Aldine.

Boxer, C.R. 1977. The Portuguese Seaborne Empire, 1415-1825. London: Hutchinson \& Co. Ltd.

Brown,'T. 1997. 'Clearances and clearings: deforestation in Mesolithic/Neolithic Britain'. Oxford Journal of Archaeology 16 (2): 133-146.

Burke, A., V. Eisenmann and G.K. Ambler. 2003. 'The systematic position of Equus hydruntimus, an extinct species of Pleistocene equid'. Quaternary Research 59: $459-469$.

Burney, D.A. and T.F. Flannery. 2005. 'Fifty millennia of catastrophic extinctions after human contact'. Trends in Ecology and Evolution 20: 395-401.

Butzer, K. 2005. 'Environmental history in the Mediterranean world: cross-disciplinary investigation of cause-and-effect for degradation and soil erosion'. Journal of Archaeological Science 32 (12): 1773-1800.

Cabral M.J.J.Almeida,P.R.Almeida,T.Dillinger, N. Ferrand de Almeida, M.E. Oliveira, J.M. Palmeirim, A.I. Queiroz, L. Rogado and M. Santos-Reis, eds. 2005. Livro Vermelho dos Vertebrados de Portugal. Lisbon: Instituto Conservação Natureza.

Caldararo, N. 2002. 'Human ecological intervention and the role of forest fires in human ecology'. The Science of the Total Environment 292: 141-165.

Carcaillet, C., H. Almquist, H. Asnong, R.H.W. Bradshaw, J.S. Carrión, M.J. Gaillard, K. Gajewski, J.N. Haas, S.G.. Haberle, P. Hadom, S.D. Muller, P.J.H. Richard, I. Richoz, M. Rosch, M.F. Sánchez-Goñi, H. von Stedingk, A.C. Stevenson, B. Talon, C. Tardy, W. Tinner, E. Tryterud, L. Wick and K.J. Willis. 2002. 'Holocene biomass burning and global dynamics of the carbon cycle'. Chemosphere 49: 845-863.

Cardoso, J.L. 2002. Pré-História de Portugal. Verbo.

Cardoso, J.L. 1994. 'Caça e criação de gado na Época Romana: seu papel na alimentação' In Portugal Romano: a exploração dos recursos naturais. Ed. Museu Nacional de Arqueologia/Instituto Português de Museus/Ministério da Cultura, 152-155.

Cardoso, J.L. 1997. 'Bases de subsistência em povoados do Bronze Final e da Idade do Ferro do território português. O testemunho dos mamíferos'. In De Ulisses a Viriato- o primeiro milénio A.C., ed. J. Alarcão (Lisbon: Instituto Português de Museus), pp. 160-173. 


\section{HISTORICAL ECOLOGY OF NORTHERN PORTUGAL}

Coelho, A.B. 2004. 'O Tempo e os Homens: Séculos XII-XIV'. In História de Portugal, ed. J. Medina (Ediclube), Vol.3, pp. 353-541..

Cortazar, J.A. 1988. 'Organizacion social de espacio: propuestas de refiexion y analisis histórico de sus unidades en la España medieval'. Studia Historica 6: 195-236.

Costa, A.C. 1706. Corografia portugueza e descripçam topografica do famoso reyno de Portugal. Lisbon: In Off. de Valentim da Costa Deslandes.

Costa, M.L. 'Naus e galeões na ribeira de Lisboa. A construção naval no século XVI para a rota do Cabo' (PhD. diss., University of Lisbon, 1993), pp. 162-227.

Costa, J.C., C. Aguiar, J.H. Capelo, M. Lousã and C. Neto. 1998. 'Biogeografia de Portugal Continental'. Quercetea 0: 5-56.

Coutinho, A.X.P. 1877. A Quinta districtal de Bragança no Anno Agricola de 1875 a 1876. Oporto: Relatório.

Coutinho.A.X.P. 1882. A Silvicultura no Districto de Bragança. These Apresentada ao Conselho Escolar do Instituto Geral de Agricultura, Lisbon.

Coudé-Gaussen, G. and M. Denèfle. 1980. 'La signification du développment récent de la land d'altitude dans le Portugal Septentrional d'aprè l'étude de deux turbières'. Bulletin de l'Association. Française pour l'Etude du Quaternaire 3: 107-115.

Coudé-Gaussen, G. 1981. Les Serras da Peneda e do Gerês. Étude geomorphologique. Memórias do Centro de Estudos Geográficos 5.

Davis, S. 2005. 'Why domesticate food animals? Some zoo-archeological evidence from the Levant'. Journal of Archaeological Science 32: 1408-1416.

Devy-Vareta, N. 1985. 'As matas medievais e a Coutada Velha' do Rei. Revista. Faculdade Letras e Geografia. I série, Vol 1: 47-67. Oporto.

Devy-Vareta, N. 1986. 'Para uma geografia histórica da floresta portuguesa'. Revista Faculdade Letras e Geografia I série, Vol 1: 5-37. Oporto.

Devy-Vareta, N. and A.A.M. Alves. 2007. 'Políticas florestais - Os avanços e os recuos da floresta em Portugal, da Idade Média ao Liberalismo'. In Série Árvores e Florestas de Portugal. Lisbon: FLAD/PÚBLICO/LPN.

Desprat, S., M.F. Goñi and M.F. Loutre. 2003. 'Revealing climatic variability of the last three millennia in northwestern Iberia using pollen influx data'. Earth and Planetary Science Letters 213: 63-78.

Dias, J. 1948. Vilarinho da furna: uma aldeia comunitária. Instituto para a alta cultura. Oporto: Centro de Estudos de Etnologia Peninsular.

Dias, J. 1953. Rio de Onor: Comunitarismo Agro-pastoril. Instituto para a alta cultura. Oporto: Centro de Estudos de Etnologia Peninsular.

Dias, J.A. 1998. 'A população'. In Nova História de Portugal, ed. J. Serrão and A.H. Oliveira Marques, Vol. 5: 11-52. Presença.

Diamond, J. 1997. Guns, Germs and Steel. New York: Vintage.

Dinis, J.L., V. Henriques, M.C. Freitas, C. Andrade and P. Costa. 2006 'Natural and anthropogenic forcing in the Holocene evolution of three coastal lagoons (Caldas da 


\section{BRUNO PINTO, CARLOS AGUIAR AND MARIA PARTIDÁRIO}

Donkor, N.T. and J.M. Fryxell. 1999. 'Impact of beaver foraging on structure of lowland boreal forests of Algonquin Provencial Park, Ontario'. Forest Ecology and Management 118: 83-92.

Fabião, C. 1992. 'O passado Proto-Histórico e Romano'. In História de Portugal. ed. J. Mattoso, Vol 1: 79-299. Círculo dos Leitores.

Fabião, C. 2004. 'A Antiguidade Tardia e a desagregação do Império'. In História de Portugal, ed. J. Medina, Vol. 3: 203-264. Ediclube.

Fernandes, H. 2004. 'Sociedade e economia nos campos-séculos XII a XIV'. In História de Portugal,. ed. J. Medina, Vol 4: 11-74. Ediclube.

Ferrão, J.E.M. 1992. A aventura das plantas e os descobrimentos portugueses. Lisbon: Instituto de Investigaçäo Científica Tropical.

Ferreira, J.M. 1994. Via Romana do Gerês (Geira) em 1728. Edição facsimilada do livro Thesouro de Braga descuberto no campo do Gerez. Câmara Municipal de Terras do Bouro.

Figueiral, I. 1995. 'Charcoal analysis and the history of Pinus pinaster (cluster pine) in Portugal'. Review of Paleobotany and Palynology 89: 441-454.

Figueiral, I. 1996. 'Wood resources in north-west Portugal: their availability and use from the Late Bronze Age to the Roman period'. Vegetation. History and. Archeobotoany 13: 219-232.

Figueiral, I. and A,M.S. Bettencourt. 2004. 'Middle/Late Bronze Age plant communities and their exploitation in the Cávado Basin (NW Portugal) as shown by charcoal analysis: the significance and co-occurrence of Quercus (deciduous)-Fabaceac'. Vegetation, History and Archeobotany 13: 219-232.

Figueiral, I. and C. Carcaillet. 2005. 'A review of Late Pleistocene and Holocene biogeography of highland Mediterranean pines (Pinus type sylvestris) in Portugal, based on wood charcoal'. Quatemary Science Reviews 24: 2466-2476.

Figueiral, I. and M.J. Sanches. 2003. 'Eastern Trás-os-Montes (NE Portugal) from the late Prehistory to the Iron Age: the land and the people'. In The Mediterranean World Environment and History, ed. E. Fouache (Amsterdam: Elsevier), pp. 315-329.

Gordon, I.J., A.J. Hester and M. Festa-Bianchet. 2004. 'The management of wild large herbivores to meet economic, conservation and environmental objectives'. Journal of Applied Ecology 41: 1021-1031.

Grove,A.T. and O. Rackham. 2001. The Nature of Mediterranean Europe. An Ecological History. New Haven, CT: Yale University Press.

Guerra, A.M. 1995. Plínio-o-Velho e a Lusitânia. Lisbon: Colibri.

Guerreiro, M.V. 1981. Pitōes das Jtinias. Esboço de monografia etnográfica. Lisbon: Serviço Nacional de Parques, Reservas e Património Paisagístico.

Gurnell, A.M. 1998. 'The hydrogeomorphological effects of beaver dam-building activity'. Progress in Physical Geography 22: 167-189.

Honrado, J. 'Flora e vegetação do Parque Nacional da Peneda-Gerês'. (Ph.D. diss., 


\section{HISTORICAL ECOLOGY OF NORTHERN PORTUGAL}

Jorge, V.O. 1990. 'Aconsolidação do sistema agro-pastoril'. In Nova História de Portugal, ed. J. Serrão and A.H. de Oliveira, Vol. 1: 102-162. Presença.

Jorge, S.O. 1999. Domesticar a terra. Trajectos portugueses 45. Gradiva.

Kay, J.J. 2000. 'Ecosystems as self-organizing holarchic open systems: narratives and the second law of thermodynamics'. In Handbook of Ecosystem Theories and Management, ed. S.E. Jorgensen and F. Muller (CRC Press-Lewis Publishers), pp. 135-160.

Lautensach, H. 1988. 'A cobertura vegetal'. In Geografia de Portugal.ed. O. Ribeiro. H. Lautensach and S. Daveau, Vol. 2: 539-565. Lisbon: Edições João Sá da Costa.

Lautensach, H. 1989. 'As bases históricas e psico-sociais da geografia humana de Portugal'. In Geografia de Portugal, ed. O. Ribeiro, H. Lautensach and S. Daveau, Vol. 3: 627-644. Lisbon: Edições João Sá da Costa.

Leão, D.N. 1735. Descrip̧̧ão do Reino de Portugal, 2nd edn. Lisbon.

Leal, A.S.P.1875. Portugal Antigo e Moderno, Vol V. Lisbon.

Leguay, J.P. 1993. 'O Portugal Germânico'. In Nova História de Portugal, ed. J. Serrão and A.H. de Oliveira Marques, Vol. 2: 13-115. Presença.

Lemos, F.S. 'Povoamento romano de Trás-os-Montes Oriental'. (Ph. D. Diss., University of Minho, 1993), pp. 504-514.

Lemos. F.S. 1997. 'Povoamento, espaço e gentilitates no $1^{\circ}$ milénio A.C. no Nordeste transmontano'. In De Ulisses a Viriato- o primeiro milénio A.C., ed. J. Alarcão (Lisbon: Instituto Português de Museus), pp. 147-153.

Levine M. 1999. 'Botai and the origins of horse domestication'. Journal of Anthropological Archaeology 18: 29-78.

Link, M. 1803. Voyage en Portugal par M. le Comte de Hoffmannsegg. Paris.

Lobo, C. A.S.S. 1903. História da sociedade em Portugal no século XV. Imprensa Nacional. Lisbon.

Magalhães, J.R. 1993. População e cconomia. In História de Portugal, ed. J. Mattoso, Vol 3: 197-353. Círculo dos Leitores.

Martins, M. 1997. 'Povoamento e habitat no noroeste português durante o $1^{\circ}$ milénio A.C'. In De Ulisses a Viriato- o primeiro milénio A.C., ed. J. Alarcão (Lisbon: Instituto Português de Museus), pp. 118-133.

Mateus, J.E. 1992. 'Holocene and present-day ecosystems of the carvalhal region, southwest Portugal'. (Ph. D. diss., University of Utrecht, 1992), pp. 12-47.

Mattoso, J. 1992a. 'A Época Sueva e Visigótica'. In História de Portugal, ed. J. Mattoso, Vol 1: 302-359. Círculo dos Leitores.

Mattoso, J. 1992b. 'Portugal no Reino Austuriano-Leonês'. In História de Portugal, ed. J. Mattoso, Vol 1: 441-565. Círculo dos Leitores.

Mattoso, J. 1993. '1096-1325'. In História de Portugal, ed. J. Mattoso, Vol. 2: 10-319. Círculo dos Leitores.

Maurer, B.A. 1999. Untangling Ecological Complexity: The Macroscopic Perspective. Chicaso. The Iniversitv of Chicaso Press. 


\section{BRUNO PINTO, CARLOS AGUIAR AND MARIA PARTIDÁRIO}

Mendes, J.L. 1968. Notícia sobre montarias nas serras do noroeste. Secretaria Estado da Agricultura. Direcção-Geral dos Serviços Florestais e Aquícolas. Lisbon.

Mendes, J.M. 1995. Trás-os-Montes nos fins do século XVIII. Fundação Calouste Gulbenkian. Junta Nacional de Investigação Científica. Lisbon.

Menezes, A.F. 2001. 'A produção'. In Nova História de Portugal, ed. J. Serrão and A H. Oliveira Marques, Vol. 7: 226-274. Presença.

Mesquita, S. Modelação Bioclimática de Portugal Continental. (Msc. diss., Technical Superior Institute, 2005), 12-45.

Monteiro-Rodrigues, S. 2000. A Estação Neolítica do Prazo (Freixo de Numão - Norte de Portugal) no contexto do Neolítico Antigo do Noroeste Peninsular : algumas considerações preliminares. In Congresso de Arqueologia Peninsular, 3, Vila Real, 1999 - Actas (Porto : Adecap), Vol. 3, pp. 149-168.

Monteiro-Rodrigues, S. 2002. 'Estação pré-histótica do Prazo - Freixo de Numão : estado actual dos conhecimentos'. Côavisão 4 :113-126.

Muñoz-Sobrino, C., P. Ramil-Rego and L. Goméz-Orellana. 2004. 'Vegetation of the Lago de Sanabria area (NW Iberia) since the end of the Pleistocene: a paleoecological reconstruction on the basis of two new pollen sequences'. Vegetation, History and Archeobotany 13: 1-22.

Muñoz-Sobrino, C., P. Ramil-Rego, L. Goméz-Orellana and R.A.D. Varela. 2005. 'Palynological data on major Holocene climatic events in NW Iberia'. Boreas 34: $381-400$.

Muñoz-Sobrino, C., P. Ramil-Rego, G. Deubes de Castro and M. Rojo Guerra. 1996. 'Datos paleobontánico sobre la Turbera de La Piedra (Páramo de Tozo, Burgos)'. In Biogeografia Pleistocena-Holocena de la Península Ibérica, ed. P. Ramil-Rego et al.: 149-162. Santiago de Compostela.

Naveh, Z. and Y. Carmel. 2003. 'The evolution of the cultural mediterranean landscape in Israel as affected by fire, grazing, and human activities'. In Evolutionary Theory and Processes: Modern Horizons, Papers in Honor of Eviatar Nevo, ed. S.P. Wasser. Kluwer Academic Publishers.

Naveh, Z. and A. Leiberman, A. 1990. Landscape Ecology. New York: Springer.

Nolet, B.A. and F. Rosell. 1998. 'Comeback of the beaver (Castor fiber): an overview of old and new problems'. Biological Conservation 83: 165-173.

Oliveira-Marques, A.H. 1986. 'Portugal na crise dos séculos XIV e XV'. In Nova História de Portugal, Vol. IV, ed. J. Serrão and A.H. Oliveira Marques. Lisbon: Presença.

Oliveira, A. and N.F. Costa. 1996. 'Um manuscrito inédito sobre o Douro Superior em finais do século XVIII'. Douro-Estudos \& Documentos 1(1): 196-258.

Oubiña, C.P. 2003. 'Looking forward in anger: social and political transformations in the Iron Age of the north-western Iberian Peninsula'. European Journal of Archaeology 6(3): 267-299.

Pereira, J.T.S. 1910. 'A 15 dias da caçada'. Ilustração portuguesa. Lisbon. 


\section{HISTORICAL ECOLOGY OF NORTHERN PORTUGAL}

Perevolotsky,A. and N.G. Seligman. 1999. 'Role of grazing in Mediterranean rangeland ecosystems. Inversion of a paradigm'. Bioscience 48(12): 1007-1017.

Pinto, M.L., J.D. Rodrigues and A.B. Madeira. 2001. 'A base demográfica'. In Nova História de Portugal, ed. J. Serrão and AH. Oliveira Marques, Vol. 7: 385-441. Presença.

Pykala, J. 2000. 'Mitigating Human effects on european biodiversity through traditional animal husbandry'. Conservation Biology 14(3): 705-712.

Radich, M.C. 1996. Agricultura no Portugal Oitocentista: uma discreta desordem. Celta.

Radich, M. and A. Alves. 2000. Dois séculos da floresta em Portugal. Lisbon: CELPA.

Ramil-Rego, P. 1993. 'Evolución cimática e história de la vegetación durante el Pleistoceno Superior y el Holoceno en las reiogiones montañosas del Noroeste Ibérico". In Pérez et al. (eds.), La evolución del paisaje en las Montañas del Entorno de los Caminos Jacobeos (Santiago de Compostela: Xunta de Galicias), pp. 25-60.

Ramil-Rego,P.,C.Muñoz Sobrino,L.Gómez-Orellana and M. Rodríguez Guitián. 1996a. 'Cambios globales del clima y los hábitats terrestres'. Férvedes 3: 9-31.

Ramil-Rego, P., C. Muñoz Sobrino, L. Gómez-Orellana and M. Rodríguez Guitián. 1996b. 'Valoración de las sequencias polínicas del norte de la Península Ibérica para el último ciclo glaciar-interglaciar'. Férvedes 3: 33-116.

Ramil-Rego,P., C. Muñoz Sobrino, M. Rodríguez Guitián and L. Gómez-Orellana. 1998. 'Differences in the vegetation of the North Iberian Peninsula during the last 16,000 years'. Plant Ecology 138: 41-62.

Rebello da Silva, L.A. 1869. História de Portugal Séc. XVII e XVIII. Imprensa Nacional.

Rego, F. 2001. Florestas públicas. Direcção-Geral Florestas. Lisbon.

Rosas. F. 1994. 'Introdução'. In Nova História de Portugal, ed. J. Serrão and A.H. Oliveira Marques, Vol. 12: 9-18. Presença.

Ruddiman. W.F. and A. MacIntyre. 1981. 'The mode and mechanism of the last deglaciation: oceanic evidence'. Quaternary Research 16: 125-134.

Ruiz-Zapata, B., A.I. Correia, S. Daveau and M. Lecompte. 1995. 'Dinámica de la vegetación durante los últimos 3000 años en la Sierra de Peneda (noroeste de Portugal), en base al análisis polínico'. In Trabajos de Palinologia Básica y Aplicada, ed. Mateu Andrés: 263-376. X Simposio de Palinogía, APLE. Universitat de València. Valencia.

Sanches. M.J. 1996. Ocupação Pré-histórica do Nordeste de Fortugal. Fundación Rei Afonso Henriques.

Sanches, M.J. 1997. Pré-História Recente de Trás-os-Montes, Vols. I and II. Sociedade Portuguesa de Antropologia e Etnologia.

Serrão, J.V. 1993. 'O quadro económico'. In História de Portugal, Vol. 4, ed. J. Mattoso,

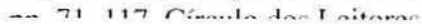




\section{BRUNO PINTO, CARLOS AGUIAR AND MARIA PARTIDÁRIO}

Sousa, A. 1993. '1325-1480’. In História de Portugal, Vol 2, ed. J. Mattoso: 310-556. Círculo dos Leitores.

Taborda, V. 1932. Alto Trás-os-Montes. Estudo geográfico. Imprensa da Universidade. Coimbra.

Trindade, M.J.L. 1981. 'A Vida Pastoril e o Pastoreio em Portugal nos Séculos XII a XVI'. In Estudos de História Medieval. Lisbon: Faculdades de Letras da Universidade Clássica de Lisboa.

Valente, M.J. 2004. 'A fauna mamológica do povoado do Fumo (Almendra. Vila Nova de Foz Côa)'. Arqueologia 7(1): 221-225.

van der Knaap, W.O. and J.F. van Leeuwen.1995. 'Holecene vegetation sucession and degradation as responses to climatic change and human activity in the Serra da Estrela Portugal'. Review of Paleobotany and Palynology 89: 153-211.

van der Knaap, W.O. and J.F. van Leeuwen. 1997. 'Late-Glacial and early-Holocene vegetation sucession, altitudinal vegetation zonation, and climate change in Serra da Estrela, Portugal'. Review of Paleobotany and Palynology 97: 239-285.

Vasconcelos, J.L. 1980. Etnografia portuguesa, Vol. II. Imprensa Nacional-Casa da Moeda. Lisbon.

Vera, F.W.M. 2000. Grazing Ecology and Forest History. CABI Publishing.

Westra, L., P. Miller, J.R. Karr, W.E. Rees and R.E. Ulanowicz. 2000. 'Ecological integrity and the aims of the global integrity project'. In Ecological Integrity: Integrating Environment, Conservation and Health, ed. D. Pimentel, L. Westra and R.F. Noss (Island Press), pp. 19-44.

Williams, M. 2000. 'Dark ages and dark areas: global deforestation in the deep past'. Journal of Historical Geography 26(1): 28-46.

Zilhão J. 2000. 'From the Mesolithic to the Neolithic in the Iberian peninsula'. In Europe's First Farmers, ed. T.D. Price (Cambridge: Cambridge University Press), pp. 144-182.

Zilhão, J. 1993. 'The spread of agro-pastoral economies across Mediterranean Europe: A view from the Far West', Journal of Mediterranean Archaeology 6: 5-63.

Zilhão, J. 1997. Súmula dos resultados científicos. Arte rupestre e Pré-Historia do Vale do Côa, ed. J. Zilhão: 13-37. Lisbon: Ministério da Cultura.

Zilhão, J. 2003. 'Vers une chronologie plus fine du cycle ancien de l'art paléolithique de la Côa: quelques hypotheses de travail'. In El arte prehistorico desde los inicios del siglo XX: Primer symposium internacional de arte prehistorico de Ribadesella, ed. R.D. Balbín and P. Buena Ramirez (Ribadesella: Asociación Cultural Amigos de Ribadesella), pp. 75-90.

\section{ARCHIVAL SOURCES}

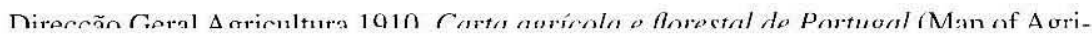

